\title{
Assessment of Foreign Decommissioning Technology with Potential Application to U.S. Decommissioning Needs
}
R.P. Allen
K. J. Schneider
G. J. Konzek
R. I. Smith

September 1987

Prepared for the U.S. Department of Energy under Contract DE-AC06-76RLO 1830

Pacific Northwest Laboratory Operated for the U.S. Department of Energy by Battelle Memorial Institute 


\section{DISCLAIMER}

This report was prepared as an account of work sponsored by an agency of the United States Government. Neither the United States Government nor any agency thereof, nor Battelle Memorial Institute, nor any of their employees, makes any warranty, expressed or implied, or assumes any legal liability or responsibility for the accuracy, completeness, or usefulness of any information, apparatus, product, or process disclosed, or represents that its use would not infringe privately owned rights. Reference herein to any specific commercial product, process, or service by trade name, trademark, manufacturer, or otherwise, does not necessarily constitute or imply its endorsement, recommendation, or favoring by the United States Government of any agency thereof, or Battelle Memorial Institute. The views and opinions of authors expressed herein do not necessarly state or reflect those of the United States Government or any agency thereof, or Battelle Mernorial Institute.

\section{PACIFIC NORTHWEST LABORATORY operated by \\ BATTELLE MEMORIAL INSTITUTE \\ for the \\ UNITED STATES DEPARTMENT OF ENERGY under Contract DE-AC06-76RLO 1830}

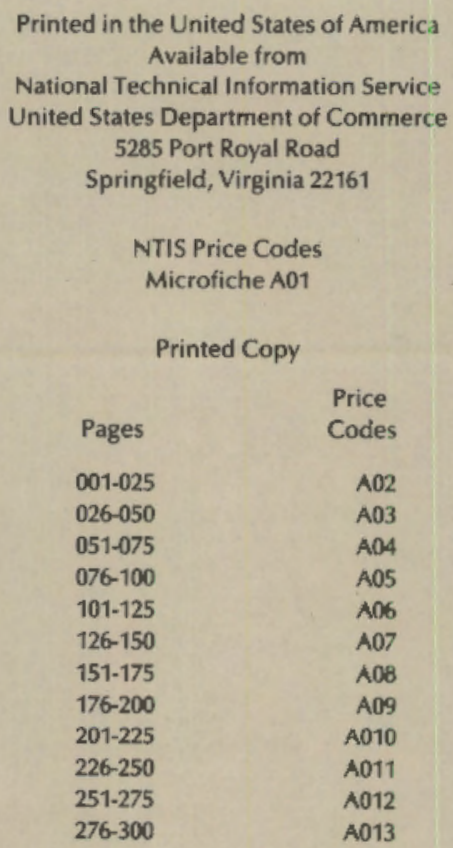


ASSESSMENT OF FOREIGN DECOMMISSIONING TECHNOLOGY WITH POTENTIAL APPLICATION TO I.S. DECOMMISSIONING NEEDS
R. P. Allen
G. J. Konzek
K. J. Schneider
R. I. Smith

September 1987

Prepared for the U.S. Department of Energy under Contract DE-AC06-76RL0 1830

Pacific Northwest Laboratory Richland, Washington 99352 


\section{SUMMARY}

This study was conducted by the Pacific Northwest Laboratory (PNL) for the J.S. Department of Fnergy (DOE) to identify and technically assess foreign decommissioning technology developments that may represent significant improvements over decommissioning technology currently available or under development in the United States. Technology need areas for nuclear power reactor decommissioning operations were identified and prioritized using the results of past light water reactor (LWR) decomissioning studies to quantitatively evaluate the potential for reducing cost and decomnissioning worker radiation dose for each major decommissioning activity.

Based on these identified needs, current foreign decomissioning technologies of potential interest to the IJ.S. were identified through personal contacts and the collection and review of an extensive body of decommissioning literature. These technologies were then assessed qualitatively to evaluate their uniqueness, potential for a significant reduction in decommissioning costs and/or worker radiation dose, development status, and other factors affecting their value and applicability to J.S. needs.

The results of the study show that the major cost elements in LWR decommissioning, and thus the activities with the greatest potential for cost savings through improved technology, are 1) management of radioactive decommissioning wastes, 2) the demolition of heavily reinforced nonradioactive structures, and 3) the detachment, removal and segmentation of fiuid systeins and components. Similarly, decommissioning worker radiation dose data show clearly that improved technology for the last category represents the major opportunity for worker dose reduction.

The technology assessment in this study indicates that there are no presently identified, fully developed foreign technologies directly applicable to major U.S. decommissioning needs that are not currently available in the IJ.S. There are, however, several promising technologies in the conceptual or R\&D/demonstration stage that should be monitored and periodically reassessed as further development and demonstration studies are conducted. These include: 
- Decontamination of metallic waste to levels permitting release as nonradioactive material using aggressive acid mixtures or decontamination agents incorporated in pastes and gels.

- Development of easily processed electrolytes, or purification processes for minimizing secondary decontamination waste volumes.

- New methods for the removal of contaminated concrete using microwave spalling or a milling cutter with accurate depth control.

- Decontanination of major reactor components and systems to reduce worker radiation dose using abrasive particles suspended in the decontamination solution, or a one-step process based on Ce(IV).

There also are several technologies that, although known or used in the J.S., are the subjects of extensive foreign R\&D, demonstration or application programs. This foreign work represents a valuable source of information on costs, waste volumes, adaptations, etc., that could be very beneficial for U.S. application of these technologies. These include:

- Melting and melt-refining of metallic waste for volume reduction and decontamination, and to facilitate assay for release and recycle.

- Use of abrasive water jet cutting, mechanical cutting and controlled blasting to demolish heavily reinforced and prestressed concrete structures.

- Use of remote operations technology and improved cutting methods to reduce worker radiation dose associated with decontamination, detachment, removal and segmentation operations.

The majority of the foreign decommissioning work reviewed for this study was directed toward one or more of the major technology need areas identified for power reactor decommissioning, thus confirming the general validity of the need identification process and the specific areas selected. No specific decomissioning technology needs were identified that are not addressed to some degree either by the foreign technology development work or by existing U.S. technology or development programs. Rased on the outcone of the ongoing R\&D work, the technology need areas that potentially could benefit most from 
additional R\&D emphasis would include improved monitoring methods for metallic waste to assure compliance with release criteria, better survey/sampling methods for contaminated concrete surfaces to guide operations on the extent of concrete removal, and cost-effective treatment processes for secondary decontamination wastes. 

CONTENTS

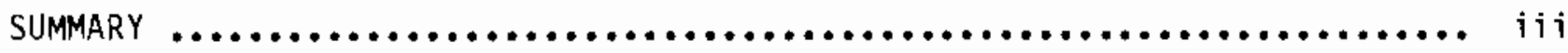

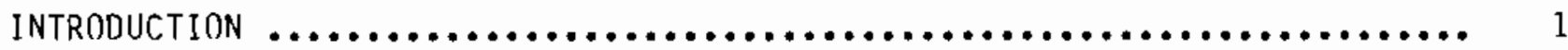

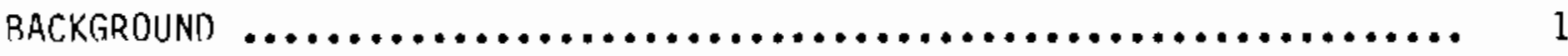

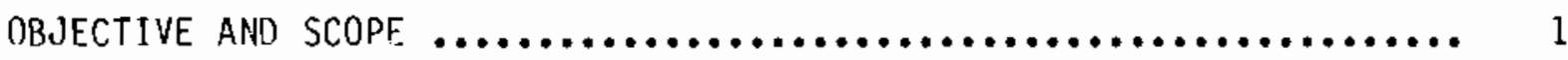

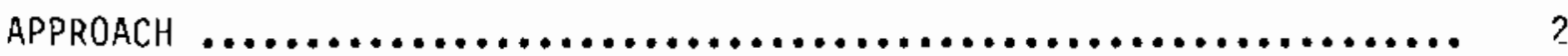

IOENTIFICATION OF DECOMMISSIONING TECHNOLOGY NEEDS $\ldots \ldots \ldots \ldots \ldots \ldots \ldots \ldots$......... 5

NUCLEAR FUEL CYCLE FACILITY DECOMMISSIONING ACTIVITIES $\ldots \ldots \ldots \ldots \ldots 5$

LIGHT WATER REACTOR DECOMMISSIONING ACTIVITIES $\ldots \ldots \ldots \ldots \ldots \ldots \ldots ., 8$

ASSESSMENT OF FOREIGN DECOMMISSIONING TECHNOLOGY $\ldots \ldots \ldots \ldots \ldots \ldots \ldots \ldots \ldots$

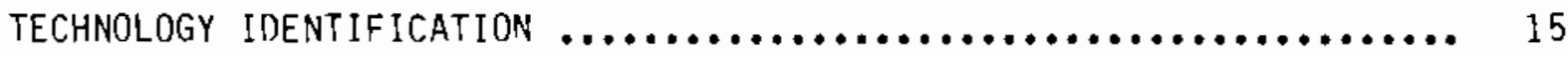

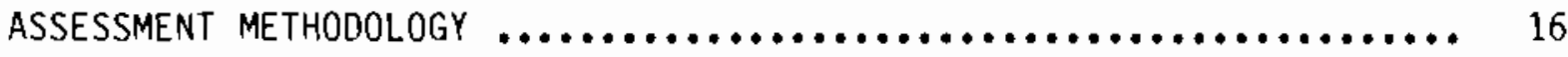

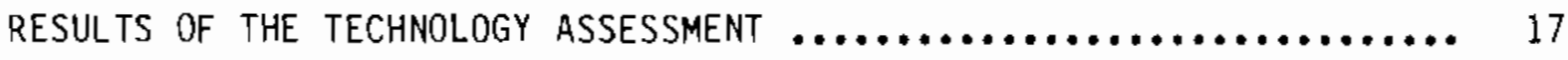

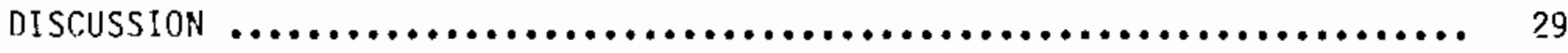

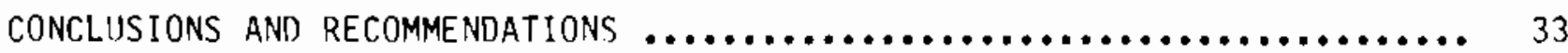

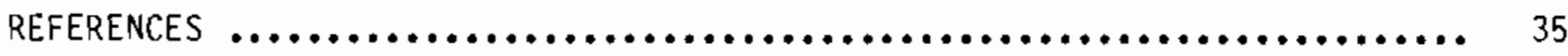

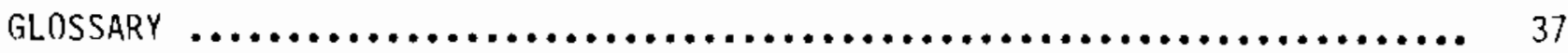

APPENDIX A - COST AND DOSE ESTIMATING BASES $\ldots \ldots \ldots \ldots \ldots \ldots \ldots \ldots \ldots \ldots$. .1

APPENDIX B - SELECTED FOREIGN DECOMMISSIDNING TECHNOLDGIES $\ldots \ldots \ldots \ldots \ldots$. B.1

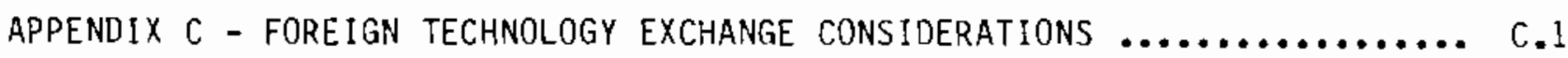




\section{TABLES}

1 Major Decommissioning Activities for Nuclear Fuel Cycle Facilities and Estimated Technology Needs ...................... 6

2 Estimated Cost and Dose Percentages for Commercial Nuclear Power Reactor Decommissioning

3 Estimates of Radioactive Waste Types, Volumes, and Management/ Disposal Costs

A.1 Estimated Cost and Dose Distribution for Decommissioning

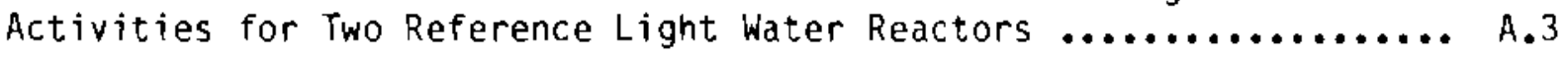

A.2 Estimates of Radioactive Waste Types, Volumes, and Distribution of Decommissioning Costs for a Reference PWR .................... A.5

A.3 Estimates of Radioactive Vaste Types, Volumes, and Distribution of Decommissioning Costs for a Reference BWR

\section{FIGURES}

1 Approach Ised to Identify Needs and Select/Assess Technologies 


\section{INTRODUCTION}

BACKGROUND

At present, a total of seven commercial nuclear power reactors in the Inited States are shut down and are undergoing or awaiting decommissioning. In addition, a total of 14 major U.S. civilian experimental reactors are shut down. By the year 2010, an estimated 40 large nuclear power reactors in the J.S. will have reached the end of their current licensing periods and will be potential candidates for decomanissioning. The Department of Energy (DOE) is assisting the U.S. commercial nuclear power industry in assuring the availability of demonstrated technology for safe and effective decommissioning of these retired nuclear power stations when it is needed. The DOE has, since 1981, sponsored a major decomanissioning program to develop and demonstrate key elements of the decontamination and decommissioning of nuclear fuel cycle facilities.

The DDE program has demonstrated that technology is available to carry out all aspects of decommissioning of these facilities. However, decommissioning is still in the demonstration phase, and some aspects of power reactor decommissioning have room for major improvement. A number of other countries with significant nuclear electric power programs are similarly facing the near-term decomissioning of older nuclear power stations, and are developing and demonstrating their related technologies. It may be of significant vaiue to the U.S. DOE decommissioning program to have access to improved decommissioning technologies under development in other countries.

\section{DBJECTIVE AND SCOPE}

The objective of this study is to identify and technically assess foreign decommissioning technology and developments that may represent significant improvements over decomissioning technology currently available or under development in the U.S. The scope of this study includes reviewing all potentially useful foreign decommissioning technology developments, with an overview evaluation of areas reflecting major IJ.S. decommissioning technology 
needs for nuclear power stations (i.e., improved equipment and methods that could significantly reduce decommissioning costs and radiation dose to decommissioning workers).

The results of this study are expected to be useful to the DOE in planning future research and developinent work and in identifying potentially beneficiat areas for international decomissioning technology exchange activities. Acquisition and application of selected foreign technologies should improve the cost-effectiveness and enhance the safety of U.S. decommissioning activities, for both the DOE and the II.S. nuclear industry.

APPROACH

As illustrated schematically in Figure 1, the study was started by first developing a list of major nuclear fuel cycle facility decommissioning activities. Next, general areas with incentives for inprovements were identified based on expert opinion and decommissioning experience. These incentives, or need areas, were further focused and prioritized for power reactor decomissioning operations by using the results of past LWR decommissioning studies (Smith et al. 1978; 0ak et al. 1980; Smith et al. 1985) to quantitatively evaluate the potential for reducing cost and decomissioning worker dose for each decommissioning activity.

Concurrently with the identification of U.S. needs, foreign decommissioning technologies of potential interest to the IJ.S. were identified through personal contacts and the collection and review of an extensive body of decommissioning literature. Initial selections were made based on apparent technical uniqueness and potential value as a source of otherwise unavailable decomissioning information. The foreign technologies in the major need areas identified for power reactor decommissioning were further assessed qualitatively to evaluate uniqueness, potential for cost and/or dose reduction, development status, and other factors affecting their value and applicability to U.S. needs. 


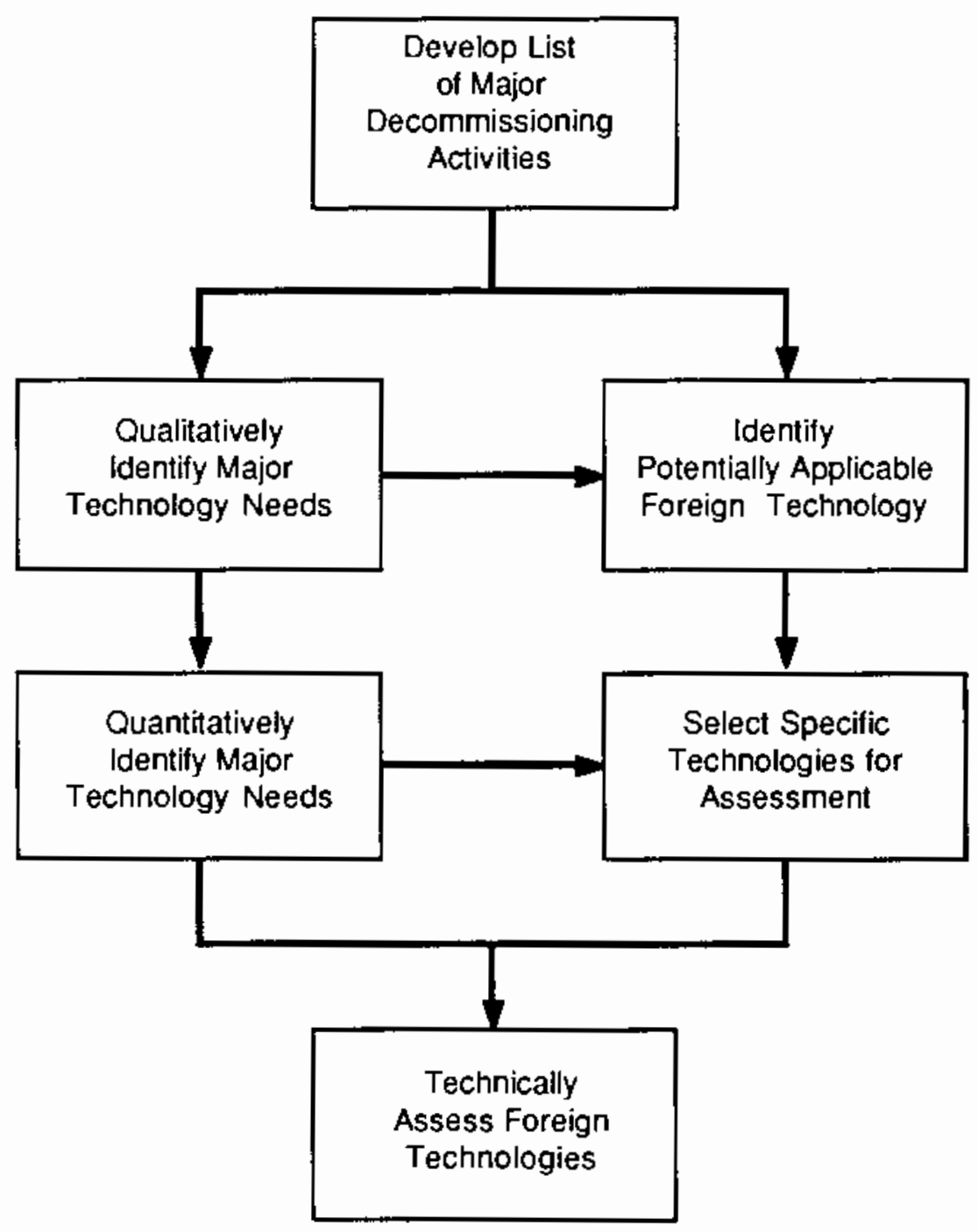

FIGURE 1. Approach Used to Identify Needs and Select/Assess Technologies 
.

: 


\section{IDENTIFICATION OF OECOMMISSIONING TECHNOLOGY NEEDS}

Nuclear fuel cycle facilities can be safely decommissioned using existing technology. The technology areas with the highest priority for improvement in this study are those decomissioning activities that result in the highest costs and/or worker radiation dose. The specific areas where technology improvements would be most beneficial were qualitatively identified by:

- Developing a list of major decommissioning activities to serve as a framework for organizing and assessing the foreign technology information. This list was hased on a review of recent decomissioning studies and projects.

- Holding two workshop sessions involving PNL staff with extensive experience and expertise in decommissioning technology and costbenefit studies to evaluate technology needs for each of the decommissioning activity categories. This evaluation included consideration of the technology needs and development directions identified in recent OECD/NEA and IAEA reports (NEA 1986, IAEA 1985).

- Personal contacts with knowledgeable individuals representing DOE and commercial decomissioning activities to identify specific technology needs related to their interests and experience.

- Evaluating decommissioning technology needs as reflected by past and current technology development programs both in the U.S. and in other countries.

\section{NUCLEAR FUJEL CYCLE FACILITY DECOMMISSIONING ACTIVITIES}

The results of the preliminary evaluation of decommissioning technology needs for generic nuclear fuel cycle facilities are summarized in Table 1 . The table shows the major activities required for decommissioning, and the authors' collective qualitative judgnent of where improved technology would be heneficial. The designations "low, moderate and high" are used to reflect the relative need for improved technology with respect to potential reductions in cost and/or worker dose. 
TABLE 1. Major Decommissioning Activities for Nuclear Fuel Cycle Facilities and Estimated Technology Needs

Decomissioning Activity

1. Planning/Engineering/Management

1.1 Pre-Decommissioning

1.2 Decomissioning

2. Preparatory Operations

2.1 Physical Inventory of Property

2.2 Radiological Characterization

2.2.1 Site Survey/Sampling

2.2.2 Facility Survey/Sampling

2.2.3 Inventory Calculation

2.3 Hazardous Materials Characterization

2.4 Site Modifications

2.5 Long-Lead Time Activities

2.5.1 Obtain Licenses and Permits

2.5.2 Procurements/Subcontracting

2.6 Worker Training

3. Direct Decomnissioning Operations

3.1 Decontamination

3.1.1 Fluid Systems

3.1.2 Hardware/Components

3.1.3 Facility Surfaces

3.1.4 Soil

3.2 Hazardous Material Removal/Handling

3.3 Disassembly/Removal

3.3.1 Electrical Equipment/HVAC

3.3.2 Fluid Systems/Components

$$
\begin{aligned}
& \text { 3.3.2.1 Detachment/Removal } \\
& 3.3 .2 .2 \text { Segmentation }
\end{aligned}
$$

3.3.3 Concrete
Technology Need

Low

Low

Moderate
Moderate
Moderate
Low
Low
Low
Low
Low
Low

Moderate

Moderate

High

$\mathrm{High}$

Moderate

Low

High

$\mathrm{High}$

$\mathrm{High}$ 
TABLE 1. (contd)

Decommissioning Activity

3.4 Interim Radiological Surveys

3.5 Demolition of Nonradioactive Structures

3.5.1 Conventional Structures

3.5.2 Heavily Reinforced Structures

3.6 Equipment/Facility Maintenance
Technology Need

Moderate

Low

High

Low

Low

High

Moderate

High

Low

Low

Moderate

Moderate

Moderate

5. Release Characterization

5.1 Site Final Survey/Sampling

Low

5.2 Facility Final Survey/Sampling

Low

6. Site Restoration

Low 
Based on the qualitative and preliminary evaluation presented in Table 1 , generic nuclear fuel cycle facility decomissioning activities that could benefit the most from new or improved technology include:

- Radiological characterization of sites and facilities: improved equipment, techniques and/or automated methods to reduce time, costs and worker radiation dose and/or to improve sharacterization associated with initial, interim and release surveys of sites and facilities.

- Decontamination: new techniques and equipment for decontaminating systems and components and for decontaminating or removing facility surfaces and coatings; development of a true soil decontamination process and/or additional methods to stabilize contamination in place.

- Disassembly, removal and demolition: better technology to reduce cost and dose and improve contamination control for detaching, removing and segmenting metallic components, and for cutting concrete and heavily reinforced structures.

- Waste management: better methods for handling, treating and minimizing the volume of decommissioning and secondary radioactive and mixed wastes; improved assay equipment to facilitate classification and segregation of wastes and release of componenis and materials for recycle/reuse.

\section{LIGHT WATER REACTOR DECOMMISSIONING ACTIVITIES}

It should be noted that the incentive areas for improved technologies identified in Table 1 are generic and will differ in number and priority for specific types of fuel cycle facilities and decomissioning operations. Since the primary focus of this study was on nuclear power reactors, the second phase of the need identification work was to quantitatively identify and prioritize the major technology needs for LWR decommissioning operations. Cost and decommissioning worker radiation dose information for each of the major decomissioning activity areas listed in Table 1 was extracted from the comprehensive 
studies on the technology, safety and costs of decommissioning commercia? nuclear power plants that were conducted for the U.S. Nuclear Regulatory Commission by PNL. (Smith et al. 1978; 0ak et al. 1980) and from a PNL study performed for the Electric Power Research Institute to develop estimates for several alternatives with potential for increasing decomissioning costs (Smith et al. 1985).

The results of this quantitative evaluation are sumarized in Table 2, using the same decomissioning activities listed in Table 1 . The cost and worker radiation dose data represent an average of the estimates for the immediate dismantlement of reference BWR and PWR reactors, with detailed vallies given in Appendix $A$. The values shown for each decommissioning activity are the percentage of the estimated total cost and worker radiation dose for the entire decomissioning operation, including the demolition of uncontaminated structures and site restoration.

The data presented in Table 2 indicate that the major cost elements in power reactor decommissioning, and thus the greatest potential for cost savings through improved technology, are 1) management of the radioactive wastes from decommissioning, 2) the demolition of heavily reinforced nonradioactive structures, and 3) the detachment, removal and segmentation of fluid systems and components. The decommissioning worker radiation dose estimates show clearly that improved technology for the detachment, removal and segmentation of fluid systems and components represents the major opportunity for dose reduction.

Waste management costs represent approximately $35 \%$ of the estimated tota1 decommissioning cost when transportation and cask and container costs are added. The packaging of waste as it is generated by the removal and segmenting operations also is part of waste management, but these costs are included in the disassembiy/removal category because they are difficult to identify separately. Table 3 contains detailed estimate data on radioactive waste types, volumes and waste management costs, to permit identification of the specific waste sources and waste management activities with the greatest potential for cost savings. The data are extracted from 0ak et a1. 1980; Smith et al. 1978; Smith et al. 1985) and, as in Table 2, represent average 
TABLE 2. Estimated Cost and Dose Percentages for Commercial Nuclear Power Reactor Decommissioning Activities (a)

Decomissioning Activity

Cost

Dose \%

1. Planning/Engineering/Management

1.1 Pre-Decommissioning

1.2 Decommissioning

7

0

8

0

2. Preparatory Operations

2.1 Physical Inventory of Property

(b)

(c)

2.2 Radiological Characterization

2.2.1 Site Survey/Sampling

(c)

(c)

2.2.2 Facility Survey/Sampling

$<1$

$<1$

2.2.3 Inventory Calculation

(b)

0

2.3 Hazardous Materials Characterization

(b)

(c)

2.4 Site Modifications (c)

$<1$

1

2.5 Long-Lead Time Activities

2.5.1 Obtain Licenses and Permits

$<1$

0

2.5.2 Procurements/Subcontracting

(b)

0

2.6 Worker Training

(c)

(c)

3. Direct Decommissioning Operations

3.1 Decontamination

3.1.1 Fluid Systems

3.1.2 Hardware/Components

3.1.3 Facility Surfaces

$<1$

2

3.1.4 Soil

(c)

(c)

3.2 Hazardous Materials Removal/Handling

(c)

(c)

3.3 Disassembly/Removal

3.3.1 Electrical Equipment/HVAC

$<1$

1

3.3.2 Fluid Systems/Components

$$
\left.\begin{array}{ll}
3.3 .2 .1 & \text { Detachment /Removal) } \\
3.3 .2 .2 & \text { Segmentation }
\end{array}\right\}
$$

\subsubsection{Concrete}

24

3.4 Interim Radiological Surveys

$<1(e) \quad<1$

3.5 Demolition of Nonradioactive Structures ( $f$ )

3.5.1 Conventional Structures

$\begin{array}{rl}2 & 0 \\ 15 & 0 \\ <1 & 1\end{array}$

3.6 Equipment/Facility Maintenance 
TABLE 2. (contd)

Decommissioning Activity

Cost $\%$

Dose \&

4. Waste Management

4.1 Radworker Practices/Contamination Control

(c)

(c)

4.2 Treatment of Liquid Waste

$<1$

$<1$

4.3 Volume Reduction of Solid Waste

(c)

(c)

4.4 Waste Categorization/Segregation

(c)

(c)

4.5 Packaging of Dry Solid Waste

$<1$

4.6 Waste Containers

8

2

4.7 Waste Transport

6

(c)

4.8 Waste Disposal

21

7

4.9 Treatment for Recycle/Reuse

(c)

(c)

(c)

5. Release Characterization

5.1 Site Final Survey/Sampling

$<1$

$<1$

5.2 Facility Survey/Sampling

$<1$

$<1$

6. Site Restoration

$<1$

0

7. Miscellaneous

TOTALS

$\frac{22(g)}{100} \quad \frac{12^{(h)}}{100}$

$\$ 95 M$

1500 (man-rem)

(a) Taken from Oak et al. 1980; Smith et al. 1978; and Smith et al. 1985.

(b) Cost included as part of activity 1.1 .

(c) Not estimated directly or treated analytically in the reference studies.

(d) Includes activities such as installing new HEPA filters, enlarging the suppression chamber access (BWR), and installing a temporary radwaste system.

(e) Although actual interim radiological survey/sampling costs are low, delays in dependent activities may impact operational costs.

(f) Includes disposal of nonradioactive waste on site or in local landfills.

(g) Includes speciaity contractors ( $\langle 1 \%)$, nuclear insurance (2\%), special toois and equipment (2\%), energy (7\%), and miscellaneous supplies (4\%).

(n) Includes an allowance of up to 1 rem per year for selected management and support staff whose radiation doses are not specifically estimated. Aiso includes miscellaneous post-defueling activities preparatory to decommissioning such as the replacement of the reactor vessel head in preparation for chemical decontamination of the reactor coolant system. 
TABLE 3. Estimates of Radioactive Waste Types, Volumes, and Management/Disposal Costs

\begin{tabular}{|c|c|c|c|c|c|c|c|c|}
\hline \multirow{2}{*}{ Waste Type } & \multirow{2}{*}{$\begin{array}{l}\% \text { of Total } \\
\text { Waste } \\
\text { Volume }(a)\end{array}$} & \multicolumn{6}{|c|}{ Percent of Total D\&D Cost } & \multirow{2}{*}{ TOTALS $(b)$} \\
\hline & & Tant & ansportation & Freinht & Bandia & Ground & Costs & \\
\hline & & & & & & & & \\
\hline Activated Concrete & 2 & $--(c)$ & -- & -- & $\cdots$ & -- & -. & -. \\
\hline Activated Metals & 2 & 2 & -- & -- & -- & -- & 3 & 5 \\
\hline $\begin{array}{c}\text { Contaminated } \\
\text { Concrete }\end{array}$ & 33 & 2 & -- & 2 & -- & 6 & -- & 10 \\
\hline Contaminated Metals & 57 & 3 & -- & 2 & -- & 10 & -- & 15 \\
\hline Dry Radwaste ${ }^{(d)}$ & 3 & -- & $\cdots$ & -- & -- & -- & -- & 1 \\
\hline Wet Radwaste (e) & 3 & 1 & $=$ & $=$ & $=$ & -- & $=$ & 2 \\
\hline TOTALS (b) & 100 & 8 & 1 & 5 & 1 & 17 & 3 & 35 \\
\hline & $\left(18,000 m^{3}\right)$ & & & & & & & $(\$ 33 M)$ \\
\hline
\end{tabular}

(a) Volume percent of radioactive waste as packaged.

(b) Values less than $1 \%$ (after rounding) are not shown; totals are rounded up to the nearest whole number.

(c) A dash indicates values less than $1 \%$.

(d) Dry solid radioactive waste includes discarded contaminated materials used in the decommissioning operations such as plastic sheeting, rags, and anti-contamination protective clothing. The volumes reflect a five-fold mechanical compaction in standard 55-gallon steel drums.

(e) Wet solid radioactive waste results from the processing of chemical decontamination solutions and contaminated water volumes. These wastes include concentrator bottoms, filter sludges, and spent demineralizer resins. The wastes are solidified and encapsulated in steel cask liners for disposal. 
values of estimates for the immediate dismantlement of the reference BWRs and PWRs. The percentages shown are the percentages of the estimated total cost for the entire LWR decommissioning operation, including the demolition of uncontaminated structures and site restoration.

The estimates in Table 3 show that the majority of the waste management costs from LWR decommissioning are associated with disposal of the contaminated metals and concrete. Although unit charges for containers, transportation and burial are externally controlled, major cost savings could be realized by substantially reducing the disposal volumes of the contaminated metals and concrete.

Combining the waste management information with the other cost and dose information from Table 2 leads to the following prioritized list of technology needs with the greatest potential for significant reductions in cost and/or radiation dose during the decomissioning of commercial LWRs:

1. New or improved technology to minimize the volume of contaminated metals requiring packaging, handling and disposal as radioactive waste; improved methods to treat or otherwise minimize secondary decontamination wastes; and better assay technology to facilitate the release of material for recycle and reuse.

2. New or improved technology to further reduce the volume of contaminated concrete requiring packaging, handling and disposal as radioactive waste.

3. New or improved technology for demolishing heavily reinforced concrete structures.

4. Adaptation and application of remote operations (robotics, automation) and system decontamination technology to reduce the high worker radiation doses associated with the detachment, removal, and segmentation of major reactor systems and components. 


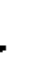

.

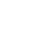

:

:

.

.

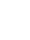




\section{ASSESSMENT OF FOREIGN DECOMMISSIONING TECHNOLOGY}

The decommissioning activity list and associated generic technology needs developed in the preceding section (Table 1) were used to identify potentially applicable foreign decommissioning technology. (The screened and reduced list of potentially applicable foreign technologies is given in Appendix R.) Specific technologies that represent the prioritized major need areas identified for decommissioning of light water power reactors were selected from this compilation and further assessed to evaluate their uniqueness, potential for cost and exposure reduction, development status, and other factors related to their value and applicability to the identified U.S. needs. The following sections describe the technology identification and assessment methodology and present the results of the technology assessments.

\section{TECHNOLOGY IDENTIFICATIDN}

Identification of foreign decommissioning technology of potential interest to the 11.S. was accomplished through personal contact with foreign technical experts; by reviewing recent IAEA and OECD/NEA reports, bulletins and research abstracts; and by reviewing foreign trip reports, industry briefs, trade journal articles, D\&D-related bibliographies, and several hundred foreign D\&D literature references (including information from the IAEA data base) obtained through the Remedial Action Program Information Center.

The preliminary selection of foreign decomissioning technologies identified in this report was based on apparent technical uniqueness and/or possible value as sources of otherwise unavailable decomissioning information. In some cases, the technology may have been conceived or developed originally in the 1).S., but subsequent foreign R\&D or application studies have resulted in technical improvements, specialized adaptations, or application experience that provide data on costs, waste volumes, or other information of potential benefit to the U.S. in applying this technology. 
The identified foreign technologies are orgalized and listed in Appendix $B$ under the general headings for the decomissioning activities outline presented in Table 1. Technologies related to remote/automated operations are grouped with the appropriate decommissioning activity. It should be noted that there is a substantial amount of potentially useful information available from foreign sources. The 68 items appearing in Appendix $B$ represent just a small part of the information base that was reviewed. Approximately 50 of these technologies appeared relevant to the power reactor technology needs and were selected for further assessment.

\section{ASSESSMENT METHODOLOGY}

The decommissioning technologies identified through the review of foreign R\&O activities were assessed technically with respect to available U.S. technology and applicability to U.S. needs. The specific evaluation factors inciuded:

- Potential for a substantial reduction in decommissioning costs compared with currently available U.S. technology

- Potential for a substantial reduction in decommissioning worker radiation dose compared with currently available U.S. technology

- Availability or development status of comparable U.S. technology

- Development status of the foreign technology; i.e., concept, R\&D program or applied process.

Other factors considered in the assessment included technical feasibility and application experience with similar processes. Accessibility of the developed/demonstrated technology, and an estimate of the effort required to implement the approach also would have to be considered before actively pursuing a given technology.

The assessment was conducted by PNL. staff with expertise in the identified technologies, supplemented as required by contacts with experts in industry and at other DoE facilities. 
RESULTS OF THE TECHNOLOGY ASSESSMENT

Application of the previously described assessment methodology to the most recent foreign decommissioning technology did not disclose any unique, developed foreign technologies that are ready for direct application to U.S. needs. There are, however, several potentialiy applicable technologies in the conceptual or R\&D/demonstration stage that should be monitored and periodically reassessed as further development and demonstration studies are conducted. In addition, there are some technologies that, although known or used in the U.S., are the subjects of extensive foreign development or application efforts that could result in technology improvements. This latter work category represents a potentially valuable source of foreign information on costs, waste volumes, specialized adaptations, etc., that could be very helpful for U.S. applications of these base technologies.

Presented below are the results of the technology assessment for each major need category. For each potentially applicable foreign technology, the organization and country are given, comments regarding the technology are presented, and recommendations on possible follow-up activities are provided. Foreign technologies that do not appear applicable and thus do not merit information exchange actions are not included here, but are retained in the list generated by the initial technology screening (Appendix B).

1. Minimization of Contaminated Metal Volumes

The objective for this category is to reduce decommissioning costs through new or improved technology to minimize the volume of contaminated metals requiring packaging, handling, and disposal as radioactive waste.

Potentially Applicable Technologies

- Technology. Use of hydrochloric acid and mixtures of hydrofluoric and nitric acids enhanced by uitrasonic agitation to decontaminate metallic decomissioning wastes to free-release levels. 
- Organization: Ente Nazionale per l'Energia Elettrica/Italy

- Comments: This is not a unique approach, but represents a current CEC research effort that will generate valuable data on effectiveness, costs and waste volumes for this type of decontamination process as adapted for decommissioning operations. Studies to date indicate good results for accessible surfaces, but difficulties in decontaminating crevice regions. Secondary waste volumes also can be relatively high.

- Recommendation: Monitor the progress and results of the ongoing research program.

- Technology. Use of strippable pastes containing acids and other decontamination agents to remove and contain surface contamination. This technique was developed to avoid aerosol formation and the generation of large volumes of decontamination and rinse solutions.

- Organizations: NUKEM; Max Morant Chemische Fabrik/FRG.

- Comments: Decontamination pastes based on metal cleaning formulations have been used in the $F R G$ for many years. Studies to develop improved, strippable formulations were initiated by NUKEM, and have been continued by the $D E C$ through research currently in progress at Max Morant Chemische Fabrik. Pastes can be very effective as a single stage decontamination process.

- Recommendation: Monitor the progress of the ongoing research program for process effectiveness (ability to decontaminate to free-release levels) and cost/benefit information.

- Technology. Incorporation of decontamination agents in gel-based media to minimize secondary waste volumes.

- Organizations: CEA, CEN Saclay/France 
- Comments: Gel-based media have been under development in France for several years. High decontamination factors were obtained in recent tests with sprayed gels containing hydrofluoric and nitric acids; however, aerosol generation is a problem.

- Recommendation: Periodically monitor progress in this technology area for additional developments and application data.

- Technology. Decontamination of stainless steel by the vapor phase transport separation of the metallic constituents using iodine as the carrier gas.

- Organization: CEA, DMG Grenoble/France.

- Comments: Thermodynamic modeling of this novel approach indicates that cobalt can be readily separated from iron and nickel, although successive treatments are required. However, it may be very difficult to separate cobalt from chromium.

- Recommendation: Monitor the progress of the modeling and subsequent experimental work to evaluate process feasibility and cost.

- Technology. Electrolyte development and processing

- Sub-Technology: Development of an easy-to-process electrolyte for decontamination by electropolishing.

- Organization: Kraftanlagen Heidelberg/FRG

- Sub-Technology: Purification of decontamination electrolytes by diffusion dialysis; purification of decontamination electrolytes by electrodeposition.

- Organization: Shinko-Pfaudier Co. Ltd./Japan

- Sub-Technology: Purification of decontamination electrolytes using anionic exchange resins; purification of decontamination electrolytes by diffusion osmosis and diaphragm electrolysis; enhancement of electrolyte purification processes by phosphorous acid reduction. 
- Organization: Mitsubishi Heavy Industries Ltd./Japan

- Comments: Electropolishing using phosphoric acid electrolytes is a very effective technique for decontaminating uncoated metallic waste to levels permitting release as nonradioactive material. However, the contaminated electrolyte is not readily amenable to treatment to produce a stable solid or to reduce disposal volumes. Moreover, chromium introduced from the electropolishing of stainless steel results in a mixed waste that may require special disposal considerations. Development of alternative electrolytes, or an effective and economical process for purifying decontamination electrolytes, including the removal of chromium, is highly desirable if electropolishing is to be used extensively to reduce contaminated metal volumes. The listed $F R G$ and Japanese technologies represent new research programs or concepts addressing this need. The FRG work, in particular, has shown encouraging results using formic or oxalic acid with potassium bromide added (to increase electrical conductivity) as a substitute for the conventional phosphoric-acid based decontamination electrolytes. Organic acids can be purified and/or destroyed using simple processes such as filtration and thermal decomposition to produce a minimum-volume waste form that is readily incorporated in cement.

- Recommendation: Monitor progress in this technology area. It may be desirable to initiate U.S. work, particularly to resolve the chromium/hazardous waste issue, if the foreign efforts are not successful.

Supporting Technologies and Information

- Technology. Melting and melt-refining of metallic waste for volume reduction and decontamination, and to facilitate assay for release and recycle. 
- Organizations: British Steel Corporation/United Kingdorn; Kernforschungsanlage Juelich GmbH; Nuclear ingenieur-Service GmbH; Siempelkamp Giesserei GmbH and Company/FRG; and SeriRdnault Ingenielrie/france

- Comments: This work is being conducted as a major cooperative CEC research program that will establish the feasibility and cost/benefits of this approach for minimizing contaminated metal volumes. Large quantities of contaminated metal have been melted in special facilities to demonstrate volume reduction and the processing of material for recycle and reuse. Recent studies also confirm the possibility of removing cesium contamination through incorporation in an acidic slag. Similar efforts to remove cobalt have not been successfut.

- Recommendation: Periodically monitor the progress of the research and demonstration activities, particularly as U.S. residual radioactivity criteria are established for recycled materials.

2. Minimization of Contaminated Concrete Volumes

The objective for this category is to reduce decommissioning costs through new or improved technology to minimize the volume of contaminated concrete requiring packaging, handling and disposal as radioactive waste.

Potentially Applicable Technologies

- Iechnology. Use of microwave heating to vaporize occluded water and spall concrete surface layers from contaminated structures and activated biological shields.

- Organizations: Japan Atomic Energy Research Institute/Japan; Building Research Establishment/United Kingdom

- Comments: Microwave spalling may prove to be an effective alternative technique for removing contaminated or activated surface concrete. Up to $3 \mathrm{~cm}$ of concrete can be removed per pass, and the equipment can be used for walls and ceilings as 
well as floors. The technology will be field-tested and compared with conventional concrete surface removal equipment as part of the JPOR dismantlement operations in 1989-90.

- Recommendation: Monitor the progress of the ongoing research and demonstration programs with particular emphasis on the ability to control the removal depth to minimize disposal volumes.

- Technology. Removal of contaminated concrete surface layers using a hydraulically operated milling cutter with accurate control of the cutting depth.

- Organization: Sato Kogyo Co. Ltd./Japan

- Comments: The major advantage of this type of concrete decontamination technology is that the sing"e pass cutting depth can be adjusted to remove only the required amount of material, thus minimizing the waste volumes. The equipment has been demonstrated in field operations, and can be scaled for use on large surface areas or in constricted spaces.

- Recommendation: Obtain additional operating data to permit detailed cost/benefit comparisons with available U.S. concrete decontamination techniques.

\section{Demolition of Reinforced Concrete Structures}

The objective for this category is to reduce decommissioning costs through new or improved technology for demolishing heavily reinforced concrete structures.

Supporting Technologies and Information

- Technology. Use of explosive demolition techniques to demotish heavily reinforced and prestressed concrete structures.

- Organizations: Taylor Woodrow Construction Ltd./United Kingdom; Battelle-Institut e.V.; Noell (G.G.) GmbH; Kernforschungszentrum Karisruhe/FRG 
- Comments: The CEC is conducting an integrated R\&D program to provide a scientific basis for the use of explosive demolition techniques for heavily reinforced and prestressed concrete structures. This includes the controlled removal of multiple layers to maintain contamination confinement, the use of shaped charges to drill charge holes, immobilization of dust, and consideration of safety, environmental impact and licensing requirements. Although the base technology is available in the U.S., the detailed information developed in this foreign program may facilitate greater use of cost-effective explosive demolition techniques, particularly where there are application constraints such as an adjacent operating nuclear station.

- Recommendation: Maintain awareness of the information developed hy the ongoing research program.

- Technology. Evaluation and demonstration of mechanical, chemical, and thermal methods for the controlled removal of reinforced concrete.

- Organizations: Taylor Woodrow Construction Ltd.; UK Central Electricity Generating Board/United Kingdom; Japan Atomic Energy Research Institute/Japan.

- Comments: The CEC has sponsored the testing and/or evaluation of a variety of concrete demolition techniques in addition to controlled blasting. These include large-diameter, diamondtipped abrasive saws; stitch drill and burst methods; expanding slurries; aggressive acids; and oxygen lance/power-assisted flame cutting. The JAERI also is developing and evaluating alternative mechanical and thermal demolition techniques including sawing, abrasive water-jet cutting, and thermal lance methods. Although these are not unique techniques, their adaptation and testing, particularly in conjunction with the Japan Power Demonstration Reactor (JPDR) dismantlement demonstration, 
will provide valuable technical and cost/benefit information on the selective removal of activated concrete and the demolition of heavily reinforced structures.

- Recommendation: Maintain awareness of the information developed by the ongoing research programs.

4. Reduction of Worker Radiation Dose

The objective for this category is to reduce the high worker radiation dose associated with the detachment, removal and segmentation of major reactor systems and components.

Potentially Applicable Technologies

- Technology. Use of suspended abrasive particles to enhance or replace the chemical decontamination of ractor primary coolant systems and other contaminated piping.

- Organization: Japan Atomic Energy Research Institute/Japan

- Comments: Chemical cleaning of reactor systems is an established decontamination technology capable of significantly reducing decommissioning worker dose. The alternative use of abrasives could reduce the volume of secondary waste containing chelating agents and chromium, but this advantage could be negated if large quantities of contaminated abrasive waste are generated.

- Recommendation: Monitor progress as this technology is further developed and demonstrated.

- Technology. Development of a one-step decontamination process for primary coolant system piping based on the use of Ce(IV) in sulfuric acid to dissolve chromium-rich corrosion films.

- Organization: Japan Atomic Energy Research Institute/Japan

- Comments: Ce(IV) decontamination technology is under development in the U.S. for specialized applications. The JAERI studies should establish the feasibility and possible benefits 
of this technique for larger-scale decontamination applications, particularly if secondary waste concerns are addressed.

- Recommendation: Monitor progress as this technology is developed and demonstrated.

- Technology. Development of a combined gouging and gas-cutting torch for the underwater dismantling of reactor pressure vessels.

- Organization: Government Industrial Research Institute/Japan.

- Use of air arc gouging followed by gas cutting to section stainless steel-clad pressure vessel stee? was originally developed and demonstrated in the U.S. A single light-weight torch that combines both functions and can cut thick sections of clad pressure vessel steel underwater has been developed and tested by the Government Industrial Research Institute and will be demonstrated by Babcock Hitachi KK in late 1987 using an underwater mockup.

- Recommendation: Review the results of the demonstration work including the amenability to remote operation.

- Technology. Development of a rotary disc knife for the remote cutting of large-diameter pipe from the inside.

- Organization: Kawasaki Heavy Industries Ltd./Japan

- Comments: This technique could reduce dose for selected pipe sectioning operations where access or other constraints prevent the use of conventional external methods. The technology will be tested as part of the JPDR decommissioning demonstration.

- Recommendation: Evaluate the technology based on the results of the JPDR tests, and compare with test results for similar IJ.S. techniques.

- Technology. Use of an electrochemical dissolution technique employing a sodium nitrate electrolyte to segment metallic components. 
- Organization: Kernkraftwerk RWE-Bayernwerk GmbH/FRG

- Comnents: This technology represents a novel application of standard electrochemical machining techniques. Possible worker radiation dose-reduction advantages could be negated by the large volumes of metal hydroxide sludge that may be produced by the process.

- Recommendation: Monitor progress as the technology is further developed and demonstrated.

Supporting Technologies and Information

- Technology. Development and use of a variety of remotely controlled in-situ electropolishing fixtures to decontaminate reactor primary coolant system piping and other major plant components.

- Organization: Kraftwerk Union $A G / F R G$

- Comments: In-situ electropolishing is a U.S. technology that has been adapted by KWU for remote operations and used extensively for a number of dose-reduction applications.

- Recommendation: Maintain awareness of the technology represented by these development/application activities.

- Technology. Evaluation of the use of lasers to cut metal components and concrete, and development of a prototype system for the remote laser cutting of radioactive structures.

- Organizations: Fiat TTG S.P.A./Italy; CEA, CEN Saclay/France; Government Industrial Research Institute/Japan

- Comments: These development and demonstration programs can provide valuable additional information on the application of industrial $\mathrm{CO}_{2}$ laser technology to the remote cutting of metal and concrete, including robotic adaptations, cost, and control of contamination and particulate emissions.

- Recommendation: Review the results of these studies for worker radiation dose reduction and process application information. 
- Technology. Remote cutting of pipe using linear shaped charges

- Organization: Battelle-Institut e.V.; Kernforschungszentruln Karlsruhe GmbH/FRG

- Comments: The unique aspect of this work is the development of detailed information addressing safety, environmental impact and licensing considerations that could facilitate the wider use of this technology for worker radiation dose-reduction purposes.

- Recommendation: Maintain awareness of the information developed by the ongoing research work.

- Technology. Development/demonstration/application of other remote operations technology

- Sub-Technology: Development and demonstration of advanced robotic remote handling systems for decommissioning applications including underwater arc saw and plasma arc torch cutting systems.

- Organization: Japan Atomic Energy Research Institute/Japan

- Sub-Technology: Development of a remote-controlled sawing/coring robot for cutting activated concrete.

- Organization: Shimizu Construction Co. Ltd./Japan

- Sub-Technology: Development of a prototype system for remote underwater plasma arc cutting.

- Organization: CEA, CEN Cadarache/France

- Sub-Technology: Adaptation of remotely-operated industrial equipment (hydraulic excavator, generator, general purpose tracked vehicle, hydraulic telescopic boom) and development of advanced sensor feedhack systems for decommissioning applications.

- Organization: Central Electricity Generating Board/Inited Kingdom 
- Comments: IJse of remote operations technology is essential to reduce worker radiation dose associated with the dismantlement of major reactor systems and components. This technology is under active development in the IJ.S. However, the extensive foreign programs in this area, while factlity-specific in some cases, offer a technology and application experience base that could be valuable for future U.S. dose-reduction efforts.

- Recomnendation: Maintain awareness of the information developed through these research and demonstration programs. 


\section{DISC:USSION}

As noted in the previous section, no developed foreign technologies directly applicable to major U.S. decommissioning needs for LWRs were identified. One reason is that demonstrated technologies that are useful for decontamination/maintenance/repair activities at operating plants, such as the low oxidation state metal ion (LOMI) chemical decontamination process developed in the United Kingdom, already have been made available to U.S. utilities by foreign firms and their U.S. subsidiaries, or via licensing agreements with U.S. service organizations.

Several potentially applicable decommissioning technologies were identified that still are in the conceptual or R\&D/demonstration stage. These should be monitored and periodically reassessed as further development and demonstration studies are conducted. As in the past, some of these technologies with applicability to power reactor station operational needs are expected to be transferred to the U.S. via the service firms serving nuclear utilities. Other technologies more relevant to dismantlement operations may similarly be transferred to support the major refurbishment activities associated with life extension efforts for nuclear power plants. In some cases, the developed technologies will be generally applicable to IJ.S. needs, but additional U.S. work may be required to adapt the technology to meet unique U.S. requirements, such as the removal of chromium from decontamination electrolytes.

The following discussion presents the evaluation of each reactor decomis sioning area with an identified incentive for improvement, and an overview evaluation of corresponding available, identified and needed technology.

\section{Minimization of Contaminated Metal Volumes}

The significant costs associated with the management of contaminated metal waste can be reduced by 1) minimizing the amount of metal classified as contaminated waste by segregating noncontaminated material followed by decontaminating amenable wastes to radioactivity levels that are low enough to permit unrestricted use, and 2) reducing container requirements and final waste volumes through size reduction, compaction, melting and careful packaging of the waste. The technologies and their status are discussed below. 
- Monitoring of metallic waste for compliance with release criteria for initial segregation or after decontamination:

Some specialized foreign technology adaptations were identified, but no new technology was identified that is not available or under development in the U.S. Major advances in field monitoring equipment and methods could have significant cost benefits for decommissioning, since the inability to completely and inexpensively monitor items can substantially increase radioactive waste disposal volumes.

- Decontamination to release levels:

A few potentially interesting foreign techniques (e.g., using aggressive acids, decontamination pastes and gels, vapor phase transport separation) were identified for further assessment. As noted earlier, the potentially most important technical contribution that was found for waste minirnization could be the development of easily processed electrolytes and/or effective purification processes for the secondary wastes from demonstrated decontamination techniques such as electropolishing.

- Size reduction, compaction, melting and packaging:

Supercompaction is a developed and applied commercial technology, and is expected to play a major role in minimizing metal waste disposal volumes. Although initially developed and demonstrated in Europe, the technology in improved form is available from U.S. Firms. Melt-refining for controlled reuse of metals and melting for volume reduction of metals also have been investigated in the U.S. Size reduction and packaging technologies are domestically available.

2. Minimization of Contaminated Concrete Volumes

The high costs associated with the management of contaminated concrete waste can be reduced by minimizing the amount of concrete removed to achieve 
the specified residual radiation levels. Depending on the established criteria, this also could include segregation of some of the removed nonradioactive concrete for on-site disposal at reduced cost. The technologies and their status are discussed below.

- Survey/sampling to determine the required removal depth and to monitor progress in meeting the established criteria:

No unique foreign technology was identified. Additional work in this area could be beneficial, particularly the development of new or improved methods to monitor radioactivity levels during concrete removal activities to permit closer control of the surface removal operations.

- Concrete removal:

Two new methods (microwave heating and a milling cutter) were identified for removing contaminated concrete surface layers. These may, when fully developed and demonstrated, have cost or control advantages over current techniques that could facilitate selective removal of the contaminated concrete. Dust control is a major problem that must be included in any evaluation of concrete removal methods.

3. Demolition of Reinforced Concrete Structures

No unique or improved foreign technology for demolishing heavily reinforced concrete structures was identified. However, an extensive foreign information base on abrasive water jet cutting, mechanical cutting and explosive demolition is being developed that could be a valuable resource for the U.S. use of similar technologies.

\section{Reduction of Worker Radiation Dose}

The high collective worker radiation dose associated with the detachment, removal and segmentation of major reactor systems and components can be reduced by decontaminating these systems and components to reduce radiation levels, by the development of improved cutting techniques, and through the application of remote operations technology. The technologies and their status are discussed below. 
- Decontamination of major reactor systems and components:

Chemical decontamination of major reactor systems and components to reduce radiation dose associated with special maintenance operations is in widespread use at 11.S. nuclear power stations, with some of the important technology and services coming from or provided by foreign organizations. Some modifications are expected to be made for decommissioning applications, since cost, effectiveness, and waste management considerations may dictate the selection of different processes or application procedures than those used for operating plants where outage time and corrosion are major concerns. The two system decontamination approaches [use of abrasive particles and $\mathrm{Ce}(\mathrm{IV})$ ] identified for further assessment may have advantages for decommissioning-related applications, particularly since damage due to excessive corrosion or the use of an abrasive would not be of concern.

- Improved cutting techniques:

Three techniques (combined gouging/gas outting, rotary disc knife cutting and electrochemical segmenting) were identified that should be evaluated after further Jevelopment and demonstration for possible advantages over currently available technology. Valuable information also is expected to be developed on the laser cutting of metals and concrete, and the remote cutting of pipe using shaped charges.

- Remote operations technology:

No unique technology was identified, but an extensive and valuable information base reflecting both R\&D and large-scale demonstrations is being developed for remote underwater cutting and segmenting operations, the remote sawing and coring of concrete, the remote decontamination of system components, and the adaptation of remotely operated industrial equipment for decommissioning applications. 
CONCLUSIONS AND RECOMMENDATIONS

The major conclusions, observations and recommendations derived from this review of foreign decommissioning technology are:

1. There are no presently identified, fully developed foreign technologies directly applicable to major U.S. decommissioning needs that are not currently available in the U.S.

2. There are a number of potentially applicable technologies that should be monitored and periodically reassessed as further development and demonstration studies are conducted. Rased on the results of this ongoing monitoring program, the useful technologies should be accessed using the channels and procedures outlined in Appendix $C$.

3. No specific decommissioning technology needs were identified that are not addressed to some degree either by the foreign technology development work or by existing IJ.S. technology or development programs.

4. There is a substantial body of potentially useful additional information available from foreign sources. The $\sim 70$ foreign decommissioning technologies selected for evaluation in this study represent just a small part of the information base that was reviewed.

5. The majority of the foreign work reviewed for this study appeared relevant to the major technology need areas identified for power reactor decommissioning, thus confirming the general validity of the need identification process and the specific areas selected.

Based on the outcome of the current domestic and foreign R\&D work, the technology need areas that might warrant future R\&D emphasis would include improved monitoring methods for metallic wastes to assure compliance with release criteria, better survey/sampling methods for contaminated concrete surfaces to guide removal operations, and cost-effective treatment processes for secondary decontamination wastes. In addition, the progress of the ongoing international decommissioning technology development and demonstration programs should continue to be monitored and technically assessed. 


.

.

. 


\section{REFERENCES}

International Atomic Energy Agency (IAEA). August 1985. Decontamination of Nuclear Facilities to Permit Operation, Inspection, Maintenance, Modification or Plan Decommissioning, International Atomic Energy Agency, Vienna.

Nuclear Energy Agency (NEA). November 1986. Decomissioning of Nuclear Facilities: Feasibility, Needs and Costs, DECD Nuclear Energy Agency, Paris.

Dak, H. D., G. M. Holter, W. E. Kennedy, Jr., and G. J. Konzek. June 1980. Technology, Safety and Costs of Decommissioning a Reference Boiling Water Reactor Power Station. NUREG/CR-0672, U.S. Nuclear Regulatory Commission Report by Pacific Northwest Laboratory.

Smith, R. I., G. J. Konzek and W. E. Kennedy, Jr. June 1978. Technology, Safety and Costs of Decommissioning a Reference Pressurized Water Reactor Power Station. NUREG/CR-D130, U.S. Nuclear Regulatory Commission Report by Pacific Northwest Laboratory.

Smith, R. I., G. J. Konzek, E. S. Murphy, and E. K. Elder. May 1985. Estimated Costs for Decomissioning Nuclear Power Facilities. EPRI NP-4012, Final Report. Prepared by Pacific Northwest Laboratory for the Electric Power Research Institute. 


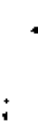




\section{GLOSSARY}

Abbreviations, acronyms, terms, and definitions used in this study and directly related to nuclear fuel cycle facilities decommissioning work and associated technology are defined in this section. The section is divided into two parts. The first contains abbreviations and acronyms and the second contains terms and definitions (including those used in a special sense for this study). Common terms covered adequately in standard dictionaries and many terms common to the nuclear industry are not included.

ABBREVIATIONS AND ACRONYMS

$\begin{array}{ll}\text { RWR } & \text { Boiling Water Reactor } \\ \text { CEC } & \text { Commission of European Communities } \\ \text { D\&D } & \text { necontamination and necomissioning } \\ \text { DOE } & \text { U.S. Department of Energy } \\ \text { FRG } & \text { Federal Republic of Germany (West Germany) } \\ \text { HEPA } & \text { High Efficiency Particulate Air filter } \\ \text { HVAC } & \text { Heating, Ventilation and Air Conditioning } \\ \text { IAEA } & \text { International Atomic Energy Agency } \\ \text { JAERI } & \text { Japan Atomic Energy Research Institute } \\ \text { JPDR } & \text { Japan Power Demonstration Reactor } \\ \text { LOMI } & \text { Low Oxidation State Metal Ion } \\ \text { LWR } & \text { Light Water Reactor } \\ \text { NRC } & \text { J.S. Nuclear Regulatory Commission } \\ \text { OECD/NEA } & \text { Organization for Economic Cooperation and Develop- } \\ \text { PNL } & \text { ment/Nuclear Energy Agency } \\ \text { PWR } & \text { Pacific Northwest Laboratory } \\ \text { R\&D } & \text { Pressurized Water Reactor } \\ \text { RPV } & \text { Research and Development } \\ & \text { Reactor Pressure Vessel }\end{array}$


GLOSSARY DEFINITIONS

Activation

Anticontamination

(Anti-C) Clothing

Biologicai

Shield

Cask (or Flask)

Chemical

Decontamination

Containment

Contamination, Radioactive

Decominission

Decontamination

Decontamination

Factor

Dismant 1 ing:

nose

Drywell

Flectromechanical Decontamination
The process of inducing radicactivity by irradiation.

Special clothing worn in a radioactively contaminated area to prevent personal contamination.

Massive and heavily reinforced concrete structure within a PWR facility used to support the reactor vessel and provide missile and radiation protection.

A massive transport container providing shielding for radioactive materials and hoiding one or more 1 iners.

Decontamination accomplished by the use of chemical solutions to remove surface films containing radioactive materials.

The retention of radioactive material in such a way that it is effectively prevented from becoming dispersed in excessive quantities.

A radioactive substance in a material or a place where it is undesirable.

To permanently remove (as a facility) from service.

Removal or reduction of radioactive contamination.

The ratio of initial content of contaminating radioactive material to the final content as a consequence of a decontamination process. (The term may refer to a specified radionuclide or to gross radioactivity.)

The removal from a site of all fuel assemblies, radioactive fluids/waste, and other materials having activities above accepted unrestricted activity levels. The facility owner may then have unrestricted use of the site with no requirements for a license. If the owner so desires, the remainder of the facility may be dismantled and all vestiges removed and disposed of.

A general term denoting the quantity of radiation or the radiation energy absorbed by a medium.

Portion of a BWR primary containment not containing the suppression pool.

Refers to the anodic removal of a mechanically resistant, radioactive surface layer under the influence of electricity and chemicals (electropolishing). 
Liner

Low-Level Waste (LLI)

Mixed Low-Leve! Radioactive and Hazardous Waste (Mixed LLW)

Noncontaminated

Nonradioactive

Off-gas Treatment

Oxyacetylene

Primary Wastes

Radioactive Waste

Radioactivity

Secondary Wastes

Shallow-Ground Disposa?
A disposable container for disposal of radioactive wastes; frequently used within shielded shipping casks during transportation.

Radioactive waste not classified as high-level waste, transuranic waste, spent nuclear fuel or byproduct material.

Waste that satisfies the definition of low-level radioactive (LLW) in the Low-Level Radioactive Waste Policy Amendments Act of 1985 (LLRWPAA) and contains hazardous waste that either 1 ) is 1 isted as a hazardous waste in Subpart D or 40 CFR Part 261 or 2) causes the LLW to exhibit any of the hazardous waste characteristics identified in Subpart $C$ of 40 CFR Part 261.

Condition when the radioactive contamination present is below the allowable standards set by regulatory agencies.

Radioactive levels (whether in the form of radiation dose rate, concentration of radioactive material contained within a matrix, or radioactive material deposited on surfaces) sufficiently low enough to be beyond regulatory concern or jurisdiction.

The removal of radioactive components or chemical pollutants from gases prior to their release under controlled conditions into the atmosphere.

oxygen and acetylene gases used in fuel cutting torches for material, piping and equipment removal.

As-generated forms and quantities of waste.

Any material that contains or is contaminated with radionuclides at concentrations or radioactive levels greater than the exempt quantities established by regulatory authorities.

The property of certain nuclides of spontaneously emitting subatomic particles or electromagnetic radiation.

Forms and quantities of all wastes that result from applying waste treatment technologies to primary wastes.

Disposal of radioactive waste, with or without engineered barriers, above or below the ground surface, where the final protective covering is a generally a few meters thick. 
Release Levels

Shielding

Shipping Cask

Surface

Contamination

Transuranic Waste

Unrestricted Area

Waste Management

Waste Treatment
Radioactive levels sufficiently low to permit release and treatment as nonradioactive material.

A material interposed between a source of radiation and personnel or equipment, etc. for protection from radiation. Common shielding materials are concrete, water, and lead.

A shielding container used for transporting and handling high-level and medium-level nuclear materials.

Contamination resulting from the disposition and attachment of foreign materials to a surface.

Waste containing nuclides with atomic numbers above 92 having quantities above agreed limits. The limits are established by national regulatory bodies.

The condition of a nuclear facility after decommissioning is complete and the facility license is terminated. At this time the general public would be allowed use of the facility without radiation protection controls.

All activities, administrative and operational, that are involved in the conditioning, transportation, storage, and disposal of waste.

Operations intended to benefit safety or economy by changing the waste characteristics. Four basic treatment concepts are defined:

- volume reduction

- immobilization of radioactivity

- change of composition

- removal of radioactivity from the waste. 
APPENDIX A

COST AND DOSE ESTIMATING BASES 


\section{APPENDIX A}

\section{COST AND DOSE ESTIMATING BASES}

The cost and occupational radiation dose evaluations used in this study are based primarily on comprehensive studies on the technology, safety and costs of decommissioning commercial nuclear power plants that were conducted for the U.S. Nuclear Regulatory Commission (NRC) by Pacific Northwest Laboratory (Smith et a1. 1978, 0ak et a1. 1980). This information was supplemented and updated with estimates from a study for the Electric Power Research Institute to develop estimates for several decommissioning alternatives with potential for increasing decommissioning costs (Smith et al. 1985).

The results of the quantitative estimates for immediate dismantlement of the reference PWR and the reference BWR, described in the Smith 1978 and 0ak 1980 references, respectively, are presented in Table A.l. The cost percent and dose percent values shown in the table are the percentages of the total cost and total dose for the entire decomissioning operation, including demolition of uncontaminated structures and site restoration. It should be recognized that the NRC does not recognize these latter two items as legitimate decommissioning costs in the Smith 1978 and Oak 1980 references because they concern facilities that are neither radioactive nor contaminated. However, they are included in this study for completeness.

The individual estimates of the cost and of the dose for each of the PWR and the BWR decommissioning activities shown in Table A.1 are combined and averaged for presentation in Table 2 in the main body of this report.

The estimates presented in Table A.l indicate that the major cost area in commercial nuclear power reactor decommissioning, thus representing the greatest potential for cost savings through improved technology, is management of radioactive decommissioning wastes. Tables A.2 and A.3 present detailed estimates of radioactive waste types, volumes, and waste management costs for the reference PWR and BWR, respectively. The percentages shown in each table are the percentages of the total cost for the immediate dismantlement of the 
respective reactors, including demolition of uncontaminated structures and site restoration but excluding any allowance for contingency (Smith et al. 1978, 0ak et al. 1980). Subsequently, the estimates for each element in the tables are combined and averaged for presentation in Table 3 in the main body of this report. 
TABLE A.1. Estimated Cost and Dose Distribution for Decommissioning Activities for Two Reference Light Water Reactors

Decommissioning Activity

1. Planning/Engineerjng/Management

1.1 Pre-Decomissioning

1.2 Decommissioning

2. Preparatory Operations

2.1 Physical Inventory of Property

2.2 Radiological Characterization

2.2.1 Site Survey/Sampling

2.2.2 Facility Survey/Sampling

2.2.3 Inventory Calculation

2.3 Hazardous Mat'ls Characterization

2.4 Site Modifications (i)

2.5 Long-lead Time Activities

2.5.1 Obtain Licenses/Permits

2.5.2 Procurements/Subcontracting

2.6 Worker Training

3. Direct Decommissioning Operations

3.1 Decontamination

3.1.1 Fluid Systems

3.1.2 Hardware/Components

3.1.3 Facility Surfaces

3.1 .4 Soil

3.2 Hazardous Mat'ls Removal/Handling

3.3 Disassembly/Remova]

3.3.1 Electrical Equipment/HVAC

3.3.2 Fluid Systems/Components

$$
\left.\begin{array}{ll}
\text { 3.3.2.1 Detachment/Removal } \\
\text { 3.3.2.2 Segmentation }
\end{array}\right\}
$$

3.3.3 Concrete

3.4 Interim Radiological Surveys

3.5 Demolition/Disposai (Nonradioactive)

3.5.1 Conventional Structures

3.5.2 Heavily Reinforced Structures

3.6 Equipment/Facility Maintenance

4. Radioactive Waste Management

4.1 Radworker Practices/Contam'n Control

4.2 Treatment of Liquid Waste and Packaging of Residuals

4.3 Volume Reduction of Solid Wastes

4.4 Haste Categorization/Segregation

4.5 Packaging of Dry Solid Wastes

4.6 Waste Containers

4.7 Waste Transport $(j)$

4.8 Waste Disposal

4.9 Treatment for Recycle/Reuse
Evaluations

\begin{tabular}{|c|c|c|c|}
\hline \multicolumn{2}{|c|}{$\operatorname{PHR}(\mathrm{a})$} & \multicolumn{2}{|c|}{$\operatorname{BHR}^{(b)}$} \\
\hline $\begin{array}{l}\% \text { Tota } \\
\text { Cost }(c)\end{array}$ & $\begin{array}{l}\text { Dot Tol } \\
\text { Dose }\end{array}$ & $\begin{array}{l}\text { b Tota } \\
\text { Cost }(e)\end{array}$ & $\begin{array}{l}\text { \% Totaf) } \\
\text { Dose }\end{array}$ \\
\hline $\begin{array}{l}7.46 \\
6.73\end{array}$ & $\begin{array}{l}0 \\
0\end{array}$ & $\begin{array}{l}6.42 \\
8.68\end{array}$ & $\begin{array}{l}0 \\
0\end{array}$ \\
\hline (g) & (h) & (g) & (n) \\
\hline $\begin{array}{l}(h) \\
0.07 \\
(g) \\
(g) \\
(h)\end{array}$ & $\begin{array}{l}(h) \\
0.90 \\
0 \\
(h) \\
(h)\end{array}$ & $\begin{array}{l}(\mathrm{h}) \\
0.01 \\
(\mathrm{~g}) \\
(\mathrm{g}) \\
0.61\end{array}$ & $\begin{array}{l}(h) \\
0.08 \\
0 \\
(h) \\
1.41\end{array}$ \\
\hline $\begin{array}{l}0.14 \\
(\mathrm{~g}) \\
(\mathrm{h})\end{array}$ & $\begin{array}{l}0 \\
0 \\
\text { (h) }\end{array}$ & $\begin{array}{l}0.10 \\
\text { (g) } \\
\text { (h) }\end{array}$ & $\begin{array}{l}0 \\
0 \\
(h)\end{array}$ \\
\hline
\end{tabular}

$\begin{array}{llll}0.17 & 1.13 & 0.16 & 2.13\end{array}$

$\begin{array}{llll}\text { (h) } & \text { (h) } & \text { (h) } & \text { (h) }\end{array}$

(h) $\quad(h)$

$\begin{array}{llll}0.72 & 1.25 & 0.26 & 0.97\end{array}$

$\begin{array}{llll}7.72 & 63.35 & 8.32 & 74.56\end{array}$

$\begin{array}{llll}2.35 & 5.58 & 0.92 & 2.43\end{array}$

$\begin{array}{llll}0.12 & 0.53 & 0.08 & 0.34\end{array}$

$\begin{array}{llll}0.45 & 0 & 2.97 & 0\end{array}$

$\begin{array}{llll}12.71 & 0 & 16.76 & 0\end{array}$

$\begin{array}{llll}0.01 & 2.04 & \text { (h) } & 0\end{array}$

(h) (h) (h) (h)

$\begin{array}{llll}\text { (h) } & \text { (h) } & 0.02 & 1.11\end{array}$

(h) (h) $\quad$ (h) $\quad$ (h)

(h) (h) (h) (h)

$\begin{array}{llll}0.20 & 2.43 & 0.09 & 2.06\end{array}$

$\begin{array}{llll}10.75 & \text { (h) } & 5.95 & \text { (h) }\end{array}$

$\begin{array}{llll}6.00 & 8.38 & 5.51 & 6.12\end{array}$

$22.16 \quad$ (h) $\quad 20.74 \quad$ (h)

(h) (h) (h) (h) 
TABLE A.1. (contd)

Evaluations

Decommissioning Activity

\begin{tabular}{ll}
\hline \multicolumn{2}{c}{ PWR (a) } \\
\hline Cotota) & Tota) \\
Cost (c) & Dose(d) \\
\hline
\end{tabular}

\begin{tabular}{|c|c|}
\hline \multicolumn{2}{|c|}{$B W R(b)$} \\
\hline $\begin{array}{l}\text { D Total } \\
\operatorname{Cost}(e)\end{array}$ & $\begin{array}{l}\text { : Total } \\
\text { Dose }(f)\end{array}$ \\
\hline
\end{tabular}

5. Facility Release Characterization

5.1 Site Final Survey/Sampling

5.2 Facility Final Survey/Sampling

$\begin{array}{llcc}(h) & 0 & (h) & 0 \\ 0.12 & 0 & 0.01 & 0 \\ 0.12 & 0 & 0.63 & 0 \\ \frac{22.00^{(k)}}{100} & \frac{14.39^{(1)}}{100} & \frac{21.77^{(m)}}{100} & \frac{8.78^{(n)}}{100}\end{array}$

6. Site Restoration

7. Miscellaneous

TOTALS $(0)$

(a) The reference pressurized water reactor is described in Smith 1978 .

(b) The reference boiling water reactor is described in 0ak 1980.

(c) The percentages of total cost are based on an adjusted totai cost of $\$ 81.1$ million in 1986 dollars, inciuding demolition of uncontaminated structures and site restoration but excluding any allowance for contingency.

(d) The percentages of total dose are based on an adjusted total decommissioning worker radiation dose of 1,181 person-rem, including transportation workers dose.

(e) The percentages of total cost are based on an adjusted total cost of $\$ 109.3$ million in 1986 dollars, including demolition of uncontaminated structures and site restoration but excluding any allowance for contingency.

(f) The percentages of total dose are based on an adjusted total occupational radiation dose of 1,879 person-rem, including transportation workers dose.

(g) Cost is included as part of activity 1.1 .

(h) Not quantified or treated analytically in the reference studies.

(i) Includes activities such as installing new HEPA filters, enlarging the suppression chamber access (BHR), and installing a temporary radwaste system.

(j) Includes cask rental costs.

(k) Comprised of the following categories, together with their respective percentages of total cost: specialty contractors (1.07\%), nuclear insurance $(1.87 \%)$, mi scellaneous supplies (4.26\%), special equipment (1.62\%), energy (8.20\%), and other expenses (4.98\%).

(1) The percentage shown could vary upward by a factor of two or more depending on 1) shutdown radiation/contamination levels, and 2) the application of ALARA considerations (CP\&L 1976). In the reference used, both plant and contractor manpower were utilized and therefore it is very difficult to establish either average exposure rates or types of personnel utilized during the referenced refueling outage. The basic assumption used in Smith et al. 1978 is that once the reactor is defueled, the reactor vessel head will be replaced in preparation for the RCS, CVCS, and related systems chemical decontamination work.

(m) Comprised of the following categories, together with their respective percentages of total cost: specialty contractors $(0.52 \%)$, nuclear insurance (1.39\%), miscellaneous supplies $(2.87 \%)$, special equipment $(2.95 \%)$, energy $(6.47 \%)$, and other expenses $(7.57 \%)$.

(n) Consists of an allowance of up to i rem per year for selected management and support staff whose radiation doses are not specifically estimated, together with an allowance of $5 \%$ of the total explicitly estimated task radiation dose, to account for any omissions and uncertainties in the analyses.

(0) Totals do not always equal exactly $100 \%$ because of the rounding of individual entries in the table. 
TABLE A.2. Estimates of Radioactive Waste Types, Volumes
of Decommissioning Costs for a Reference PWR $(z)$ and Distribution

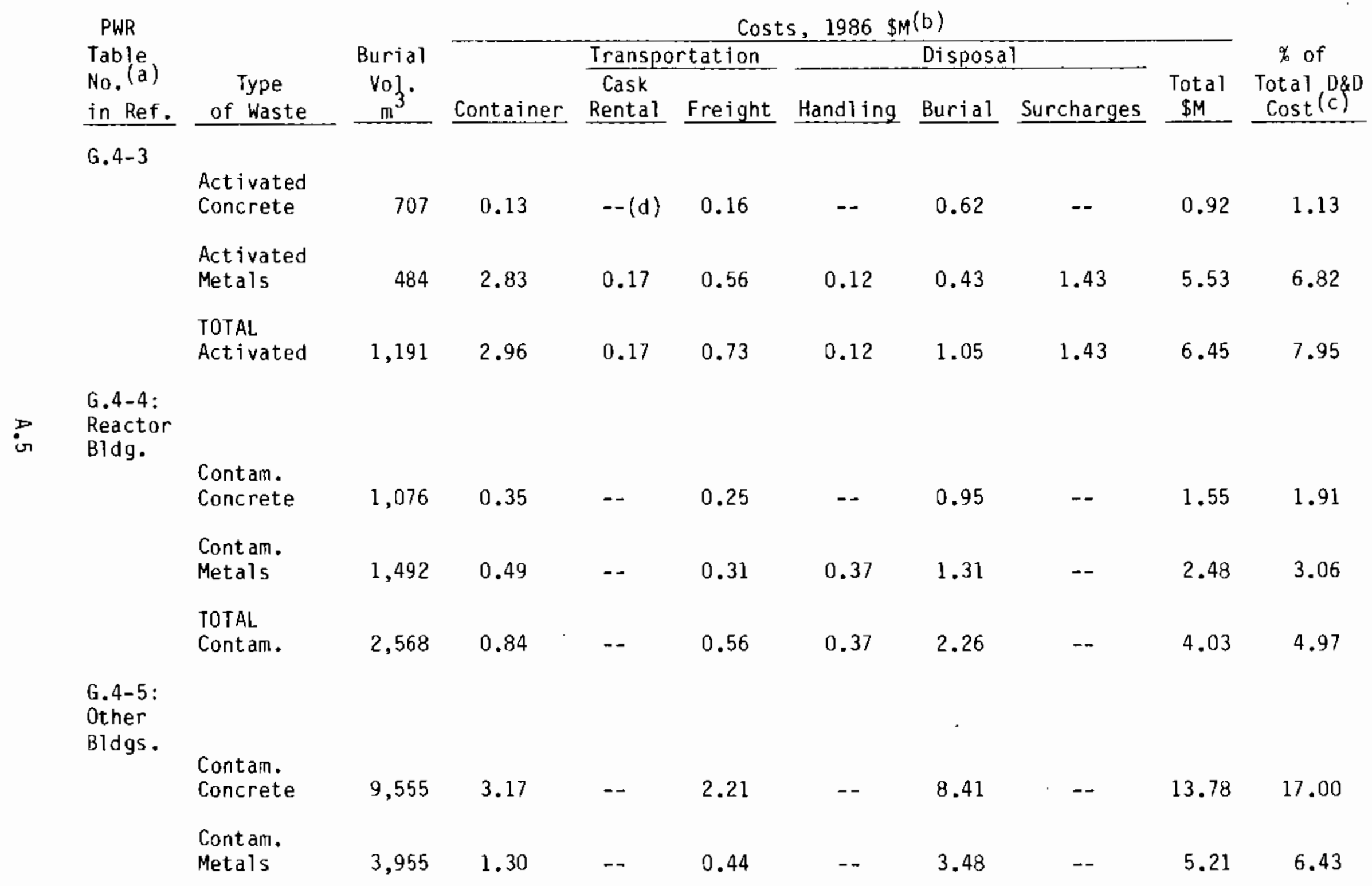


TABLE A.2. (contd)

PWR

Table (a)

G.4-5:

Other

Bldgs.

(contd) TOTAL

$$
\text { Contam. }
$$

$$
13,510
$$

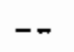

2.65

$--$

11.89

$--$

18.99

23.43

G.4-6: Dry

Radwaste (e)

286

0.03

0.04

0.20

0.04

0.25

$-$

0.57

0.70

Wet

Radwaste(f)

332

0.42

$0.12 \quad 0.40$

0.09

0.29

0.19

1.50

1.85

TOTAL
Radwaste

$618 \quad 0.45$
..-

17,887

8.71

\begin{abstract}
0.13
\end{abstract}

0.54

0.19

2.07

2.55

TOTALS

$\begin{array}{lll}17,887 & 8.71 & 0.33\end{array}$

(a) See Smith et al. 1978 for a description and additional details.

(b) Costs do not include a contingency allowance.

(c) The percentages of total cost are based on an adjusted total estimated cost of $\$ 81.1$ million in 1986 dollars, including demolition of uncontaminated structures and site restoration but excluding any allowance for contingency.

(d) A dash indicates that no cost was assigned to this item in Smith et al. 1978.

(e) Dry solid radioactive waste in this study includes discarded contaminated materials used in the decommissioning operations such as plastic sheeting, rags, and anticontamination clothing. The volumes reflect a five-fold mechanical compaction in standard 55-gallon steel drums. Steel, concrete and other materials that were from the operating nuclear power station are not included in this category.

(f) Wet solid radioactive waste in this study results from the processing of chemical decontamination solutions and contaninated water volumes. The wastes are solidified and encapsulated in steel cask liners for disposal. 
TABLE A.3. Estimates of Radioactive Waste Types, Volumes
of Decommissioning Costs for a Reference BWR $(a)$

BWR

$$
\text { Table }
$$

Type

in Ref. of Waste

8urial
Vol.

Transportation

I. 3-3

Activated

vol.

Container

Cask Disposal

$\%$ of

Concrete

Metals

$90 \quad 0.14$

--(d) 0.05

0.05

0.08

$-$

0.32

0.29

$138 \quad 0.53$

$0.41 \quad 1.05$

0.30

0.12

4.52

6.93

6.34

TOTAL

Activated

$228 \quad 0.67$

0.41

1.10

0.35

0.20

4.52

7.25

6.63

$\div$ 1.3-4:

\section{Contam.}

Concrete

1,676

0.54

0.45

0.15

1.48

$--$

2.61

2.39

Contam.

Meta1s

15,543

4.35

2.35

0.50

13.67

$-$

20.87

19.10

TOTAL.

Contam.

$$
17,219
$$

4.89

2.80

$0.65 \quad 15.15$

$-$

23.48

21.49

I. 3-5:

Dry
Radwaste (e)

678

0.08

0.14

0.30

0.10

0.61

$-$

1.23

1.13 
TABLE A.3. (contd)

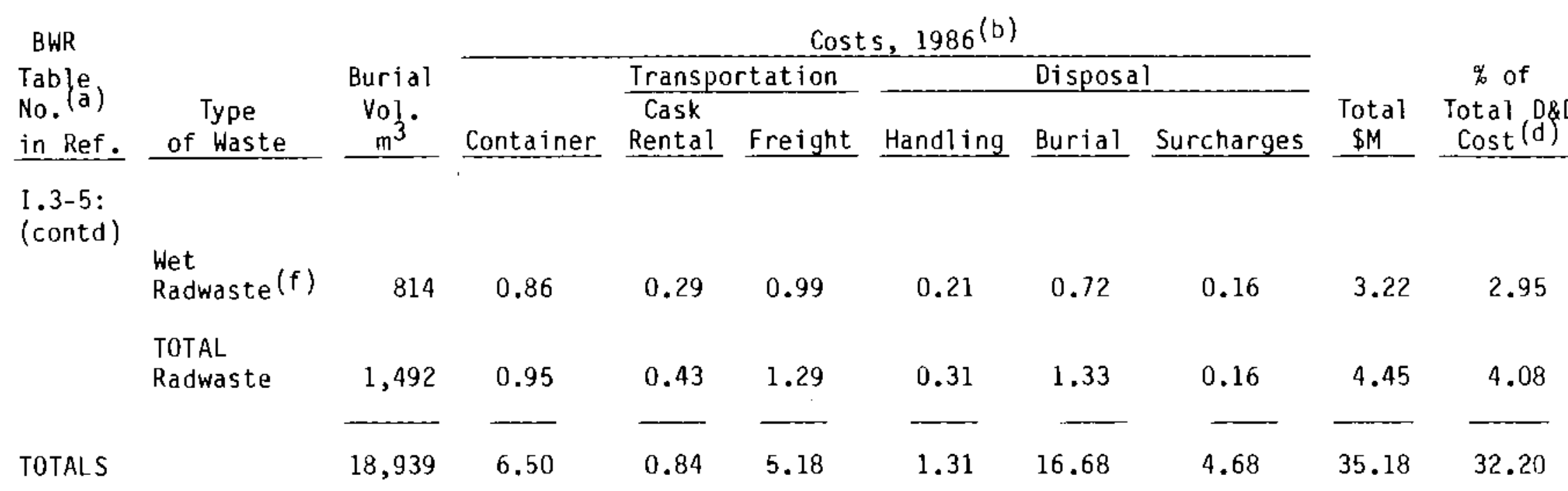

(a) See Oak et al. 1980 for a description and additional details.

(b) Costs do not include a contingency allowance.

(c) The percentages of total cost are based on an adjusted total estimated cost of $\$ 109.3 \mathrm{million}$ in 1986 dollars, including demolition of uncontaminated structures and site restoration but excluding any allowance for contingency.

(d) A dash indicates that no cost was assigned to this item in 0ak et al. 1980.

(e) Dry solid radioactive waste in this study includes discarded contaminated materials used in the decommissioning operations such as plastic sheeting, rags, and anticontamination clothing. The volumes reflect a five-fold mechanical compaction in standard 55-galion steel drums. Steel, concrete and other materials that were from the operating nuclear power station are not included in this category.

(f) Wet solid radioactive waste in this study results from the processing of chemical decontamination solutions and contaminated water volumes. The wastes are solidified and encapsulated in steel cask liners for disposal. 
REFERENCES FOR APPENDIX A

Carolina Power and Light Company (CP\&L). January 1976. "Radiation Exposure Rreakdown During the H. B. Robinson Unit ? Refueling Outage in 1975." Memorandum dated January 6,1976 , File NG-3600x1, Serial NG-76-013, Carolina Power \& Light, Raleigh, North Carolina.

Oak, H. D., G. M. Holter, W. E. Kennedy, Jr., and G. J. Konzek. June 1980. Technology, Safety and Costs of Decommissioning a Reference Boiling Water Reactor Power Station. NUREG/CR-0672, U.S. Nuclear Regulatory Commission Report by Pacific Northwest Laboratory.

Smith, R. I., G. J. Konzek, E. S. Murphy, and E. K. Elder. May 1985. Estimated Costs for Decommissioning Nuclear Power Facilities. EPRI NP-4012, Final Report. Prepared by Pacific Northwest Laboratory for the Flectric Power Research Institute.

Smith, R. 1., G. J. Konzek and W. E. Kennedy, Jr. June 1978. Technology, Safety and Costs of Decommissioning a Reference Pressurized water Reactor Power Station. NUREG/CR-0130, U.S. Nuclear Regulatory Commission Report by Pacific Northwest Laboratory. 
4 


\section{APPENDIX R}

SFLECTED FOREIGN DECOMMISSIONING TECHNOLOGIES 
APPENDIX B

SELECTEO FOREIGN DECOMMISSIONING TECHNOLOGIES

Foreign decommissioning technologies of potential interest to the U.S. were identified through personal contact with foreign technical experts; by reviewing recent IAEA and OECD/NEA reports, bulletins and research abstracts; and by reviewing foreign trip reports, industry briefs, trade journal articles, D\&D-related bibliographies, and several hundred foreign D\&D literature references (including information from the IAEA data base) obtained through the Remedial Action Program Information Center.

Specific foreign technologies that address the prioritized U.S. major need areas identified for the decommissioning of light water reactors were selected from the numerous references reviewed. The selection was based on apparent technical uniqueness and/or possible value in the U.S. as sources of otherwise unavailable decommissioning information.

The identified foreign technologies are organized and listed in this appendix under the general headings used for the decommissioning activities outline presented in Table 1 . Technologies related to remote/automated operations are grouped with the appropriate decomissioning activity.

1. Planning/Engineering/Management

Technology: Development of a model and computerized code system for planning and managing reactor decomissioning operations. Drganization: Japan Atomic Energy Research Institute Ref. Date: 1987

2. Preparatory Operations

Technology: Comparison of calculated and measured radiological survey data for the WAGR.

Organization: United Kingdom Atomic Energy Authority

Ref. Date: 1985

Technology: Comparison of calculated and measured radioactivation and depth distribution data for the Lingen and Gundremmingen biological shields. 
Organizations: Kernkraftwerk Lingen GmbH; Kernkraftwerk RWE-Bayernwerk GmbH/FRG; CEA, CEN Saclay/France

Ref. Date: 1984

Technology: Computer programs to facilitate the measurement of lowlevel gamma contamination.

Organization: Imperial College/United Kingdom

Ref. Date: 1987

Technology: Development and verification of a computerized code system for estimation of radioactive inventories.

Organization: Japan Atomic Energy Research Institute

Ref. Date: 1987

3. Direct Decommissioning Operations

Technology: Reactor primary system decontamination using suspended abrasive particles to enhance or reptace chemical cleaning action.

Organization: Japan Atomic Energy Research Institute

Ref. Date: 1987

Technology: Reactor primary system decontamination using a one-step decontamination process based on Ce (IV).

Organization: Japan Atomic Energy Research Institute

Ref. Bate: 1987

Technology: Use of gas agitation to enhance the chemical cleaning of reactor piping.

Organization: Toshiba Corporation/Japan

Ref. Date: 1985

Technology: Decontamination of components to release levels using

aggressive chemicals with ultrasonic enhancement.

Organization: Ente Nazional per 1'Energia Elettrica/Italy

Ref. Date: 1982-1987

Technology: Decontamination using various modifications of water ice blasting.

Organizations: Mitsubishi Heavy Industries, Ltd.; Kurtia Water Industries Ltd.; Ishikawajima-Harima Heavy Industries Co., Ltd./ Japan; Wroclaw Technical University/Poland; University of British Columbia

Ref. Dates: 1982-1984

Technology: Further development of dry ice blasting decontamination technology.

Organization: Power Reactor and Nuclear Fuel Development Corporation/ Japan

Ref. Date: 1985 
Technology: Decontamination of metal surfaces using plasma arc gouging.

Organization: Hitachi Ltd./Japan

Ref. Date: 1983

Technology: Decontamination of metal surfaces by thermal cycling and mechanical shock to form and spall surface oxides.

Organization: Toshiba Corporation/Japan

Ref. Date: 1983

Technology: Decontamination of surfaces using an electric discharge to activate reactive gases.

Organizations: Battelle-Institut e.V.; ALKEM/FRG

Ref. Dates: $1982 / 1983$

Technology: Decontamination using strippable pastes containing aggressive chemicals.

Organizations: Max Morant Chemische Fabrik; NUKEM/FRG

Ref. Dates: $1983 / 1987$

Technology: Decontamination using strippable coatings containing decontamination agents.

Organization: Fujikurakase Kasei Co., Ltd./Japan

Ref. Date: 1984

Technology: Decontamination using gel-based media containing decontamination agents.

Organization: CEA, CEN Saclay, Cadarache/France

Ref. Date: 1984/1987

Technology: Decontamination of metal surfaces using neutral electro-

Organization: Hitachi Ltd./Japan

Ref. Dates: 1984/1985

Technology: Electrochemical decontamination of metal surfaces using electrolyte-saturated pads.

Organizations: Toshiba Corporation/Japan; Sociezede Travaux en Lilieu Ionisant/France

Ref. Date: 1982/1987

Technology: Decontamination of reactor primary system piping by insitu electropolishing using remotely controlled fixtures.

Organization: Kraftwerk Union AG/FRG

Ref. Date: 1987

Technology: Development of a robot for decontaminating reactor well and maintenance pit surfaces.

Organization: Chubu Electric Power Co., Inc./Japan

Ref. Date: 1984 


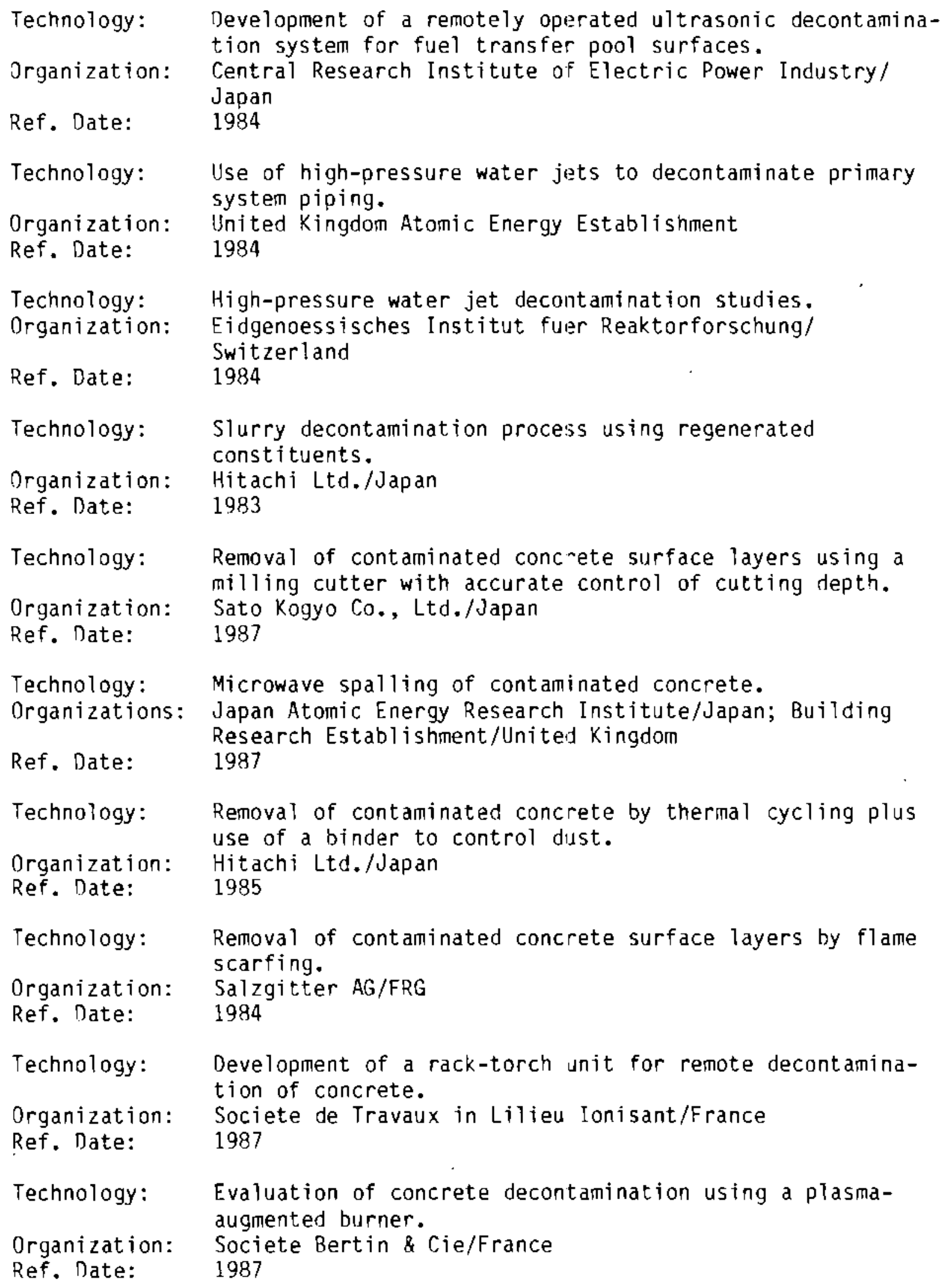


Technology: Selective removal of contaminated concrete using explosive demolition techniques.

Organizations: Battelle-Institut eV; Noell (G.G.) GmbH/FRG; Taylor Woodrow Construction Limited/United Kingdom

Ref. Dates: 1983-1987

Technology: Combined gouging and gas cutting torch for underwater cutting of reactor pressure vessels.

Organization: Government Industrial Research Institute/Japan

Ref. Dates: 1982-1986

Technology: Combined plasina arc/gas cutting of clad pressure vessel steel.

Organization: IJniversity of Hannover/FRG

Ref. Dates: 1982-1984

Technology: $\quad$ Further development and demonstration of underwater plasma arc cutting.

Organizations: Japan Atomic Energy Research Institute; IshikawajimaHarima Heavy Industries Co., Ltd.; Kawasaki Heavy Industries Ltd./Japan

Ref. Dates: 1982-1987

Technology: Development of advanced robotic remote handing systems for underwater cutting and other decommissioning applications.

Organization: Japan Atomic Energy Research Institute

Ref. Date: 1987

Technology: Development of a prototype system for remote underwater plasma arc cutting.

Organization: CEA, CEN Cadarache/France

Ref. Date: 1987

Technology: Development and demonstration of an underwater arc saw cutting system.

Organization: Japan Atomic Energy Research Institute

Ref. Date: 1987

Technology: Laser cutting of metal components and concrete.

Organization: Fiat TTG S.P.A./Italy

Ref. Date: 1984-1987

Technology: Development of a prototype system for remote laser cutting of radioactive structures.

Organization: CEA, CEN Saclay/France

Ref. Date: 1987

Technology: Remote control pyrotechnic device to cut plates and tubes. Organization: CEA, CEN Paris/France

Ref. Date: 1983 
Technology: Explosive cutting of pipe using shaped charges (including safety, environmental impact and licensing considerations).

Organization: Battelle-Institut e.V./FRG

Ref. Date: 1987

Technology: Electrochemical technique for segmenting metal components. Organization: Kernkraftwerk RWE-Bayernwerk/FRG

Ref. Date: 1987

Technology: Liquid meal embrittlement (fissuration cutting) technique

for segmenting metal components.

Organization: CEA, CEN Grenoble/France

Ref. Date: 1986

Technology: Inside disc cutter system for remote cutting of pipe.

Organization: Kawasaki Heavy Industries Lt.d./Japan

Ref. Date: 1985

Technology: In-situ arc cutting of tubes and pipes from the inside.

Organization: Field Automation/France

Ref. Date: 1987

Technology: Adaptation of remotely operated industrial equipment for decommissioning applications.

Organization: Central Electricity Generating Board/United Kingdom

Ref. Date: 1987

Technology: Development of a single-frequency illumination system to facilitate remote viewing of flame cutting operations.

Organization: Inited Kingdom Atomic Energy Authority

Ref. Date: 1987

Technology: Segmenting of components using large, stationary saws.

Organization: CEC/Luxembourg

Ref. Date: 1984

Technology: Remote controlled sawing/coring robot for cutting activated concrete.

Organization: Shimizu Construction Co., Ltd./Japan

Ref. Date: 1987

Technology: Localized concrete cutting using blasting techniques.

Organization: Swedish Cement and Concrete Research Institute

Ref. Date: 1983

Technology: Abrasive water jet cutting of concrete using iron grit. Organization: Japan

Ref. Date: 1984 
Technology: Explosive demolition techniques for heavily reinforced and prestressed concrete structures (including safety, environmental impact and licensing considerations).

Organizations: Taylor Woodrow Construction Ltd./United Kingdom; BattelleInstitut e.V.; Kernforschungszentrum Karlsruhe/FRG

Ref. Dates: 1985/1987

4. Waste Management

Technology: Development of an easy-to-process electrolyte for electropolishing.

Organization: Kraftanlagen Heidelberg/FRG

Ref. Date: 1987

Technology: Purification of decontamination electrolytes by diffusion dialysis.

Drganization: Shinko-Pfaudler Co., Ltd./Japan

Ref. Date: 1984

Technology: Purification of decontamination electrolytes by electrodeposition.

Drganization: Shinko-Pfaudler Co., Ltd./. Japan

Ref. Date: 1985

Technology: Purification of decontamination electrolytes using anionic exchange resins.

Organization: Mitsubishi Heavy Industries Ltd./Japan

Ref. Date: 1984

Technology: Purification of decontamination electrolytes by diffusion osmosis and diaphragm electrolysis.

Organization: Mitsubishi Heavy Industries Ltd./Japan

Ref. Date: 1985

Technology: Enhancement of electrolyte purification processes by phosphorous acid reduction.

Organization: Mitsubishi Heavy Industries Ltd./Japan

Ref. nate: 1985

Technology: Volume reduction of chemical decontamination wastes by neutralization.

Organization: Mitsubishi Kakoi Kaisha Ltd./Japan

Ref. Date: 1985

Technology: Purification of liquid decontamination wastes by activated carbon electrolysis.

Organization: Hitachi Ltd./Japan

Ref. Date: 1984

Technology: Volume reduction of organic decontamination wastes using ozone and UV irradiation. 
Drganization: UGC Corporation/Japan

Ref. Date: 1985

Technology: Melting and melt-refining of metal waste for volume reduction, to facilitate assay, and/or for recycle.

Organizations: British Steel Corporation/United Kingdom;

Kernforschungsanlage Juelich GmbH; Nuclear IngenieurService GmbH; Siempelkamp giesserei GmbH and Company/ FRG; and Seri-Renault Ingenielrie/France

Ref. Dates: 1984-1987

Technology: Decontamination of metallic waste by zone refining.

Organization: Hitachi L.td./Japan

Ref. Date: 1985

Technology: Decontamination of stainless steel by vapor phase transport separation.

Drganization: CEA, DMG Grenoble/France

Ref. Date: 1987

5. Release Characterization

Technology: Development of an extremely sensitive gamma scanner for low-level waste.

Organization: Japan Atomic Energy Research Institute

Ref. Date: 1987

Technology: Optimization of measurement techniques for very low-level radioactive material.

Organization: Kraftwerk Union AG/FRG

Ref. Date: 1987

Technology: Automated measuring system for release of decommissioning wastes.

Organization: NIS Nuklear-Ingenieur-Service GmbH/FRG

Ref. Date: 1987 
APPENDIX C

FOREIGN TECHNOLOGY EXCHANGE CONSIDERATIONS 
APPENDIX C

FOREIGN TECHNOLOGY EXCHANGE CONSIDERATIONS

Cooperative exchange of technology with other countries and with multinational agencies (e.g. the C,EC) is done routinely in numerous technical areas, including the nuclear power field and the specific area of decominissioning of nuclear facilities. Cooperative exchange of technology is usually done through the mechanism of bilateral agreements or multilateral agreements that are set for a specific length of time, commonly about 5 years.

The nOF. currently has bilateral exchange agreements on nuclear facility decommissioning technology with five countries (Canada, Federal Republic of Germany, France, Japan, and the United Kingdom). The DOE also participates in a cooperative program on decomissioning with the NEA through a liaison committee and a technical advisory group. The DOE participates in a coordinated research program on decommissioning with the IAEA, as well as in IAEA technical committees to develop state-of-technology and international consensus technical reports. DOE participation in these activities of these multinational groups provides a forum for general knowledge of what technology is being developed in other countries.

The DOE also has bilateral agreements in spent fuel and high-level radioactive waste management with 8 countries (the same 5 countries identified above plus Belgium, Sweden, and Switzerland), as well as an agreement with the CEC. necommissioning technology is included in most of the agreements in the more general field of radioactive waste management.

Thus, there is considerable experience and precedence in technology exchange with other countries or multinational agencies in decommissioning and related fields. Where it is determined that technology exchange and cooperation with almost any of the non-Cominuist bloc countries would be beneficial to the II.S., it is likely that it could be implemented. 
Plans for cooperative exchange of technical information should take into account many factors, including the three identified here that tend to inhibit. cooperative exchange:

- U.S. technology is generally well documented and available publicly, in a significant level of detail. It is available to virtually any enterprise for the purchase costs of the documents. As a result, the U.S. frequently has very little new to offer in cooperative exchanges.

- Private enterprise in the U.S. and in most western countries is relatively aggressive in obtaining and commercializing new or improved technologies. Generally speaking, private industry will quickly pick up and market U.S. or foreign technology to a world-wide market if business growth and/or profits will result.

- A number of other countries develop nuclear zechnology through government/private corporations or through gove'nnment subsidies, and make available the technology to others only on a commercial basis. This concept tends to restrict technology exchange with those governments.

Nevertheless, cooperative exchange of technologies has and will continue to take place to the benefit of the U.S. nuclear power industry.

Following is a general listing of the types of cooperative exchange that may be considered for implementation when planning technical exchanges with other countries.

- Fxchange listings of documents on specific subjects.

- Exchange specific documents on specific subjects, including pians, R\&्ष results, data.

- Exchange identification of private organizations with specific expertise or interest. This could involve DnE providing liaison for U.S. businesses.

- nbtain information by review of existing literature. 
- Carry out visits, briefings, consultations among appropriate experts on specific subjects to obtain technology details.

- Exchange reviews of and comments on national plans, facilities and hardware, R\&D results, data, etc.

- Exchange identification of international organizations and their contact persons who may have information of use to the various parties.

- Fxchange visiting scientists to work temporarily in the other country to assist them and to learn first-hand about their technology.

- Carry out joint development and/or demonstration programs.

- Telephone consultations among technical experts

- Exchange technical models and computer codes for use in analysis.

- Exchange materials, samples, or equipment for evaluation or testing.

- Carry out joint seminars on subjects of interest.

- Participate in international technical conferences.

- Co-deverop technical reports on technical issues or subjects.

- Co-develop feasibility reports, state-of-the art reports, survey reports.

- Participate in coordinated research programs on specific subjects.

- Outright purchase of technology. 
.

.

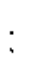

.

, 
No. of

Copies

OFFSITE

S. M. Altman

U.S. Department of Energy

Savannah River Dperations Office

P.0. Box A

Aiken, SC 29802

H. L. Apodaca

U.S. Department of Energy

Albuquerque Operations Office

P.0. Box 5400

Albuquerque, NM 87115

J. E. Baublitz

U.S. Department of Energy

NE-20

Washington, DC 20545

J. J. Blakes? ee

Rocky Flats Plant

Building 750

P.0. Box 464

Golden, C0 80402-D464

L. E. Boing

Argonne National Laboratory

9700 South Cass Avenue

Building 2D1

Argonne, IL 60439

J. A. Coleman

U.S. Department of Energy

$\mathrm{NE}-24$

Washington, DC 20545

C. R. Cooley

U.S. Department of Energy

$\mathrm{RW}-40$

Washington, OC 20545
No. of

Copies

F. P. Crimi

General Electric Company

Shippingport Station

Decommissioning Project

P. 0 . Box 325

Shippingport, PA 15077

G. H. Daly

U.S. Department of Energy

DP-124

Washington, DC 20545

W. P. Davis

Monsanto Research Corporation

P.0. Box 32

Miamisburg, OH 45342

J. E. Diekhoner

U.S. Department of Energy

DP-14

Washington, DC 20545

J. C. Elder

Los Alamos National Laboratory

P.0. Box 1663

MS K483

Los Alamos, NM 87545

J. J. Fiore

U.S. Department of Energy

NE-23 (GTN)

Washington, DC 20545

F. F. Gorup

U.S. Department of Energy

Chicago Operations office

9800 South Cass Avenue

Argonne, IL 60439

G. R. Grandbouche

U.S. Department of Energy

Grand Junction Operations office

P.0. Box 2567

Grand Junction, CO 81502 
No. of

Copies

R. J. Grandfield

U.S. Department of Energy

Dayton Area Office

P.0. Box 66

Mi amisburg, OH 45342

G. K. Hovey

Bechtel Nationa1, Inc.

P.0. Box 350

Oak Ridge, TN 37831

J. Jaffe

U.S. Department of Energy

IE-12

Washington, OC 20545

M. R. Jugan

U.S. Department of Energy

Oak Ridge Operations Office

P.0. Box E

Oak Ridge, TN 37831

A. F. Kluk

U.S. Department of Energy

DP-124

Washington, DC 20545

K. S. Kotti

Savannah River Plant

Building 703A

E23IN

Aiken, SC 29808-0DD1

T. S. LaGuardia

TLG Engineering, Inc.

Route 67, Box 237

Bridgewater, CT 06752

S. Lichtman

U.S. Envi ronmenta 1

Protection Agency

ANR -460

401 M Street, SW

Washington, DC 20460
No. of

Copies

M. E. Long

U.S. Department of Energy

San Francisco Operations Office

P.0. Box 1446

Canoga Park, CA 91304

E. Maestas

U.S. Department of Energy

West Valley Project Office

P.0. Box 191

West Valley, NY 14171

D. Majumdar

U.S. Department of Energy

Idaho Operations Office

785 DOE Place

Idaho Falls, ID 83402

W. J. Manion

Nuclear Energy Services, Inc.

Shelter Rock Road

Danbury, CT 06810

R. H. Meservey

EG\&G Idaho, Inc.

P.0. Box 1625

Idaho Falls, IO 83415

W. E. Murpiie (7)

U.S. Department of Energy

NE -23

Washington, DC 20545

R. Nelson

U.S. Department of Energy

Weldon Spring Site Remedia?

Action Project office

Route 2, Highway 94 South

St. Charles, MO 63303

P. T. Owen

Oak Ridge National Laboratory

Building 2001

P.0. Box $X$

Dak Ridge, TN 37831-6050 
No. of

Copies

S. Parker

Electrical Power Research Institute

$3412 \mathrm{Hillview}$ Avenue

Palo Alto, CA 94304

R. F. Potter

UNC Geotech, Inc.

P.0. Box 14000

Grand Junction, CO 81502-5504

W. C. Rask

U.S. Department of Energy

Rocky Flats Area Office

Building 115

P.0. Box 464

Golden, CO 80402-0464

J. W. Ray

Battelle Columbus Division

$505 \mathrm{King}$ Avenue

Columbus, $\mathrm{OH} 43201$

F. C. Schrag

Rockwell Internationa?

6633 Canoga Avenue

MS T-020

Canoga Park, CA 91303

J. J. Schreiber

U.S. Department of Energy

Shippingport Station Decoinmissioning Project office

P.0. Box 335

Shippingport, PA 15077

C. Serpan

U.S. Nuclear Regulatory Commission

Mai1 Stop 5650-NL

Washington, DC 20555

D. Tonkay

Office of Technical Services

20251 Century Boulevard

4th Floor

Germantown, MD 20874
No. of

Copies

J. R. Trabalka

Oak Ridge National Laboratory

Building 1505

P.0. Box $X$

0ak Ridge, TN 37831-6036

G. P. Turi

U.S. Departinent of Energy

NE -23

Washington, BC 20545

W. R, Voigt, Jr.

U.S. Department of Energy

NE-20

Washington, DC 20545

2 DOE Technical Information Center

ONSITE

2 DOE Richland Operations office

C. E. Miller (2)

2 Westinghouse Hanford Co.

H. F. Daugherty

R. L. Miller

24 Pacific Northwest Laboratory

R. P. Allen (10)

W. W. Ballard

G. J. Konzek

L. T. Lakey

D. R. Payson

K. J. Schneider

R. I. Smith

J. L. Straalsund

Publishing Coordination (2)

Technical Information (5) 


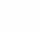
$\checkmark$
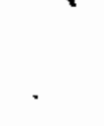